Check for updates

Cite this: RSC Adv., 2019, 9, 2498

Received 20th December 2018 Accepted 14th January 2019

DOI: $10.1039 / \mathrm{c} 8 \mathrm{ra} 10424 \mathrm{~g}$

rsc.li/rsc-advances

\section{Synthesis and biological evaluation of 2,2- dimethylbenzopyran derivatives as potent neuroprotection agents $\hat{\dagger}$}

\author{
Fangyu Du, ${ }^{\mathrm{a}}$ Qifan Zhou, ${ }^{\mathrm{a}}$ Xiaoxiao Fu, ${ }^{\mathrm{b}}$ Yajie Shi, ${ }^{\mathrm{a}}$ Yuanguang Chen, ${ }^{\mathrm{a}}$ Wuhong Fang, ${ }^{\mathrm{a}}$ \\ Jingyu Yang*b and Guoliang Chen (D) *a
}

\begin{abstract}
The development of novel neuroprotection agents is of great significance for the treatment of ischemic stroke. In this study, a series of compounds comprising 2,2-dimethylbenzopyran groups and cinnamic acid groups have been synthesized. Preferential combination principles and bioisostere that improved the neuroprotective effect of the compounds were identified for this series via biological activity assay in vitro. Meanwhile, a functional reversal group of the acrylamide amide resulted in the most active compounds. Among them, BN-07 significantly improved the morphology of neurons and obviously increased cell survival rate of primary neurons induced by oxygen glucose deprivation (OGD), superior to clinically used anti-ischemic stroke drug edaravone (Eda). Overall, our findings may provide an alternative strategy for the design of novel anti-ischemic stroke agents with more potency than Eda.
\end{abstract}

\section{Introduction}

Ischemic stroke is one of most common cerebrovascular diseases that seriously endangers human health and features high incidence, high recurrence, high disability and high fatality. ${ }^{\mathbf{1 1 2}}$ Ischemic stroke causes extensive cellular loss that impairs brain functions, resulting in severe disabilities. Despite being a major public health concern, effective disease management strategies for the treatment of ischemic stroke are limited. The need to develop effective therapeutic approaches for treating stroke is compelling. Currently, anti-ischemic stroke drugs that are in clinical trials or launched mainly include thrombolytic drugs, antiplatelet aggregation drugs, neuroprotective drugs, and drugs promoting angiogenetic effects.,

Among multiple treatment strategies implicated in the pathogenesis of ischemia, neuroprotection is the most attractive protocol. Clinical drugs mainly play a role in different pathophysiological stress processes that mediate brain tissue damage after ischemic stroke, including vascular dilation and increasing cerebral blood flow, ${ }^{5,6}$ antioxidative stress, ${ }^{7}$ antiapoptosis, $^{8}$ inhibiting excitotoxicity ${ }^{9}$ and inhibiting inflammation. ${ }^{\mathbf{1 0}}$

${ }^{a}$ Key Laboratory of Structure-Based Drug Design \& Discovery of Ministry of Education, Shenyang Pharmaceutical University, Shenyang 110016, P. R. China. E-mail: spucgl@ 163.com

${ }^{b}$ Department of Pharmacology, Shenyang Pharmaceutical University, Shenyang 110016, P. R. China. E-mail: yangiingyu2006@gmail.com

$\dagger$ Electronic supplementary information (ESI) available. See DOI: $10.1039 / \mathrm{c} 8 \mathrm{ra} 10424 \mathrm{~g}$
Ischemia causes a shortage of glucose and oxygen and thus a consumption of ATP, which results in the failure of the sodium potassium pump and leads to membrane depolarization. Then, the membrane depolarization conversely induces multiple mechanisms, involving increasing intracellular calcium, triggering cell death signalling pathways such as apoptosis, autophagy, and necroptosis. ${ }^{11}$ The increase of intracellular calcium triggers the production of reactive oxygen species (ROS), which initiates cell death cascades and activates inflammatory responses, consequently resulting in ischemic neuronal death. ${ }^{12}$ Therefore, increased oxidative stress has been considered as the primary cause. Although ROS can be cleaned by a defense system in normal tissues, superabundant ROS can result in neuronal damage or death under an ischemic condition because the antioxidant defense system is interrupted. ${ }^{\mathbf{1 3 - 1 6}}$ Therefore, ROS scavengers may represent potential candidates for the treatment of brain ischemia injury. Many approaches have been indicated to reduce the generation of ROS and to block the ROS-mediated neuronal cell death, involving utilization of antioxidants or inhibitors of cell death signalling molecules. ${ }^{17-19}$

Zang et al. discovered that pyrano[3,2-a]carbazole alkaloid 1 was an effective agent against ischemic stroke (Fig. 1) exhibited potent activity to scavenge free radical. ${ }^{20}$ Meanwhile, a previous study reported that a kind of benzopyran derivatives 2 (Fig. 1) could protect against ischemia on the stroke model of mice, the symptoms and physiological functions were obviously improved after administration. ${ }^{21}$ Edaravone (5-methyl-2-phenyl1,2-dihydropyrazol-3-one, Fig. 1), a free radical scavenger, has been approved by the PMDA of Japan as a new drug mainly for the treatment of ischemic stroke since $2001 .^{22}$ In a multicenter, 
randomized, placebo-controlled, double-blind study on acute ischemic stroke patients, edaravone represents a neuroprotective agent which is potentially useful for the treatment of acute ischemic stroke, because it can exert significant effects on outcome as compared with placebo. ${ }^{23}$

Previous studies have demonstrated that 2,2-dimethylbenzopyran derivatives and cinnamic acid analogues are important natural active compounds with broad pharmacological activities, such as antibacterial, anti-tumor and neuroprotection. ${ }^{24-28}$ Luo and Agon et al. disclosed that cinnamic acid analogues such as caffeic acid, ferulic acid, cinnamic acid could enhance the activity of lactate dehydrogenase (LDH), superoxide dismutase (SOD) and lower the malondialdehyde (MDA) contents, which were used to protect cardiovascular system. ${ }^{29,30}$ Inspired by the neuroprotective activity and the outstanding structure of 2,2-dimethylbenzopyran derivatives and cinnamic acid analogues, we therefore designed and synthesized a novel of benzopyran compounds using molecular hybridization approach, affording compounds BA-01-BA-07. Meanwhile, we replaced benzene ring with following aromatic cycles, including pyridine, thiophene, furan and naphthalene according to bioisostere, giving compounds BA-08-BA-11. Meanwhile, functional group reversal was induced in many cases to obtain compounds BN-01-BN-05 and further modifications were carried out to obtain compounds BN-06-BN-10. Excitingly, experimental results of oxygen glucose deprivation (OGD) model displayed that some novel compounds exhibited better activity of neuroprotection than edaravone.

\section{Results and discussion}

\subsection{Chemistry}

The synthetic routes for the designed compounds are shown in Schemes 1 and 2. In general, 3-chloro-3-methylbut-1-yne (3) was easily prepared from commercially available 2-methylbut-3-yn2-ol (2). (E)-3-Argioacrylic acid derivatives (Scheme 1) were either purchased or synthesized in one step from commercially available aromatic aldehyde (4a-4k) condensed with malonic acid via Knoevenagel condensation to give $\mathbf{5 a - 5 k}$. Commercially available 4-acetamidophenol (6) reacted with 3-chloro-3methylbut-1-yne (3) by Williamson ether synthesis in the presence of $\mathrm{CuCl}$ to give 7 . The subsequent high temperature facilitated $[3,3]-\sigma$ rearrangement of 7 afforded $N$-(2,2-dimethyl$2 H$-chromen-6-yl)acetamide (8) using diphenyl ether as a solvent. Treatment of 8 with $50 \% \mathrm{NaOH}$ aqueous deprotected the acetyl group from the amine moiety, and heating in the

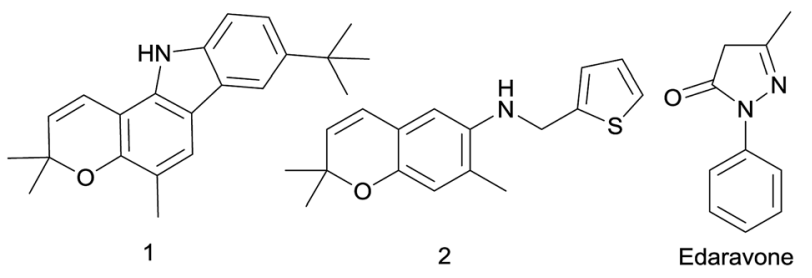

Fig. 1 Structures of 2,2-dimethylbenzopyran derivatives and edaravone. presence of ethanol, and then generated the key intermediate 2,2-dimethyl- $2 H$-chromen-6-amine (9). The synthesis of various substituted 2,2-dimethylbenzopyran derivatives BA-01-BA-11 (Scheme 1) was accomplished using a common intermediate 9 which coupled to the cinnamic acid analogues 5a-5k under standard amide coupling conditions (EDCI, HOBt, THF) as shown in Scheme 1.

The synthesis of BN-01-BN-10 (Scheme 2) began with the use of Williamson ether synthesis to transform the phenolic hydroxyl group present in 4-hydroxybenzaldehyde $\mathbf{1 0}$ to ether to provide 11. The alkyne group in $\mathbf{1 1}$ was then rearranged by treatment with high temperature in $\mathrm{N}, \mathrm{N}$-dimethylaniline to afford the corresponding aldehyde 12. This entity was condensed with malonic acid to afford the key intermediate carboxylic acid 13 via Knoevenagel condensation. Target compounds BN-01-BN-10 were made in a similar fashion of amide coupling starting from commercially available substituted aniline and substituted phenol. Interestingly, addition reaction was occurred simultaneously at the position of $\alpha, \beta$-unsaturated double bond in the

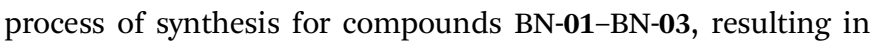
three novel compounds BN-08-BN-10.

\subsection{In vitro biological activity assay}

To explore the therapeutic potential of BA-01-BA-10 and BN-01$\mathrm{BN-11}$, in this study, we applied an in vitro oxygen glucose deprivation (OGD) model of primary cortical neurons cultures to investigate whether the series of compounds protected neurons against ischemic stroke.

2.2.1 Identification of primary neuron. Primary neuron cultures from the cortices of new born rats within $24 \mathrm{~h}$ were prepared as previously described. Microscopically, it was observed that the primary cortical neurons of the rats, cultured on the 7th day, were basically mature, evenly distributed in various fields of view. Meanwhile, the cell bodies and synapses were clearly defined, and the synapses were connected into a network (seeing ESI, Fig. S1†).

$\beta$-Tubulin is the skeletal protein of neuron which can represent location and shape of neuron. As shown in Fig. 2, neurons were evenly distributed in the field of view and only a small amount of nucleus didn't show the maker of green fluorescence (Fig. 2). $\beta$-tubulin III and DAPI double fluorescent staining showed that the isolated neurons were successfully cultured in vitro with high purity $(>90 \%)$, which can be used for the subsequent experiments. ${ }^{31}$

2.2.2 Cell viability and morphological assay. With the better purity and morphology of cultured primary cortical neurons in hand, we firstly examined the viability of normal neurons after administration at a dose of $100 \mu \mathrm{M}$. Our investigations have shown that BA- $(01,02,03,04,07,08,09)$ and $\mathrm{BN}-$ (09, 10) significantly reduced cell survival rate of normal neurons (Table 1) which suggested that these compounds were cytotoxic at this dose.

To further investigate the neuroprotective effects exerted by the interesting compounds, we next attempted to assess cell viability against OGD model after administration by MTT method using edaravone as a positive drug. Cultured cortical 


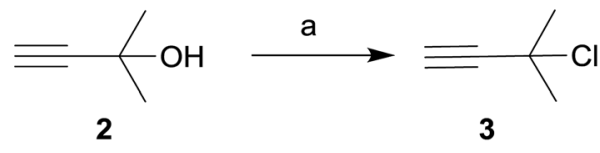

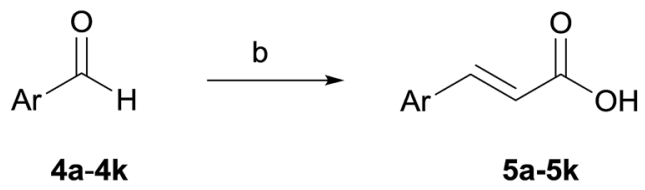

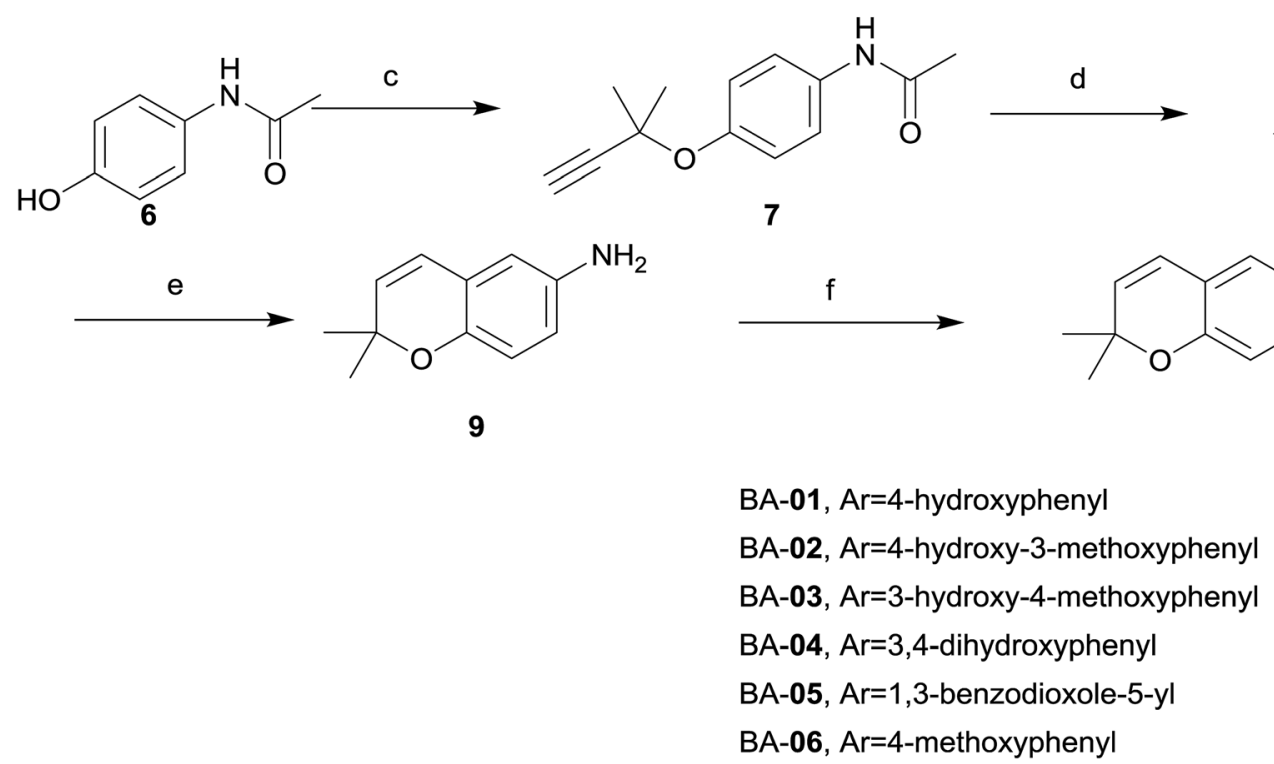<smiles>CC(=O)Nc1cbc2c(c1)C=CC(C)(C)O2</smiles>

Scheme 1 Synthesis of $\mathrm{BA}$ compounds. Reaction and conditions: (a) $\mathrm{CuCl}, \mathrm{CaCl}_{2}$, conc. $\mathrm{HCl}$, r.t., 1 h; (b) $\mathrm{CH}_{2}(\mathrm{COOH})_{2}$, pyridine, piperidine,

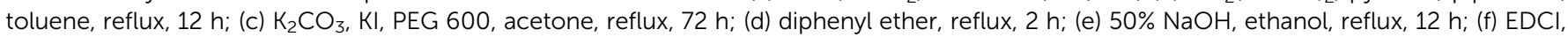
HOBt, THF, r.t., 14 h.

neuron of SD rats were randomly divided into control group, model group, positive control group, and test group $(1 \mu \mathrm{M}, 30$ $\mu \mathrm{M}, 100 \mu \mathrm{M})$. As shown in Table 2, cell viability was significantly decreased $(p<0.001)$ after OGD treatment for $12 \mathrm{~h}$ compared with the control, which indicated that OGD model was succeed. For BA compounds, the results showed that compounds BA- $(\mathbf{0 3}$,
$05,07,08,09,11)$ could significantly improve the survival rate of neuron (OGD $12 \mathrm{~h}$ ) at a dose of $1 \mu \mathrm{M}(P<0.05)$.

Another dose of compounds could decrease the survival rate of neurons or reveal no significant improvement (Table 2, and ESI, Fig. S2 $\dagger$ ). According to the results, the ring of cinnamic acid analogues had a better activity when substituted with dialkoxy<smiles>O=Cc1ccc(O)cc1</smiles>

10<smiles>C#CC(C)(C)Oc1ccc(C=O)cc1</smiles>

11<smiles>CC1(C)C=Cc2cc(C=O)ccc2O1</smiles>

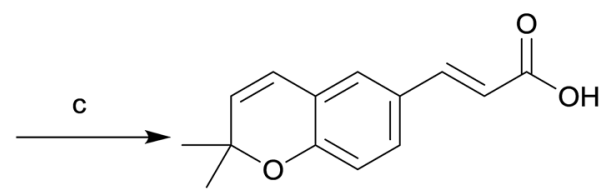

13<smiles>[R1]C(=O)/C=C/c1ccc2c(c1)C=CC(C)(CCC)O2</smiles>

BN-01 BN-07<smiles>[R]C(=O)CC([R])c1ccc2c(c1)C=CC(C)([O])O2</smiles>

BN-08 BN-10

$$
\begin{aligned}
& \text { BN-01, } \mathrm{R}^{1}=-N \text {-phenyl } \\
& \text { BN-02, } \mathrm{R}^{1}=-N-(4-\text { methoxyphenyl) } \\
& \text { BN-03, } \mathrm{R}^{1}=-N-(3-\text { methoxyphenyl) } \\
& \text { BN-04, } \mathrm{R}^{1}=-N-(2-\text { methoxyphenyl) } \\
& \text { BN-05, } \mathrm{R}^{1}=-O-\text { phenyl }
\end{aligned}
$$

$\mathrm{BN}-06, \mathrm{R}^{1}=-4-(4-$ methoxyphenyl)piperazin-1-yl $\mathrm{BN}-07, \mathrm{R}^{1}=-4$-(4-hydroxyphenyl)piperazin-1-yl $\mathrm{BN}-08, \mathrm{R}^{2}=-\mathrm{N}$-phenyl BN-09, $\mathrm{R}^{2}=-\mathrm{N}$-(4-methoxyphenyl) $\mathrm{BN}-10, \mathrm{R}^{2}=-\mathrm{N}-$ (3-methoxyphenyl)

Scheme 2 Synthesis of BN compounds. Reaction and conditions: (a) DBU, $\mathrm{CuCl}$, acetonitrile, r.t., 4 h; (b) $\mathrm{PhNMe}_{2}, \mathrm{reflux} 2$ h; (c) $\mathrm{CH}_{2}(\mathrm{COOH})_{2}$, pyridine, piperidine, toluene, reflux, 12 h; (d) HX-Ar, EDCl, HOBt, THF, r.t., 14 h. 

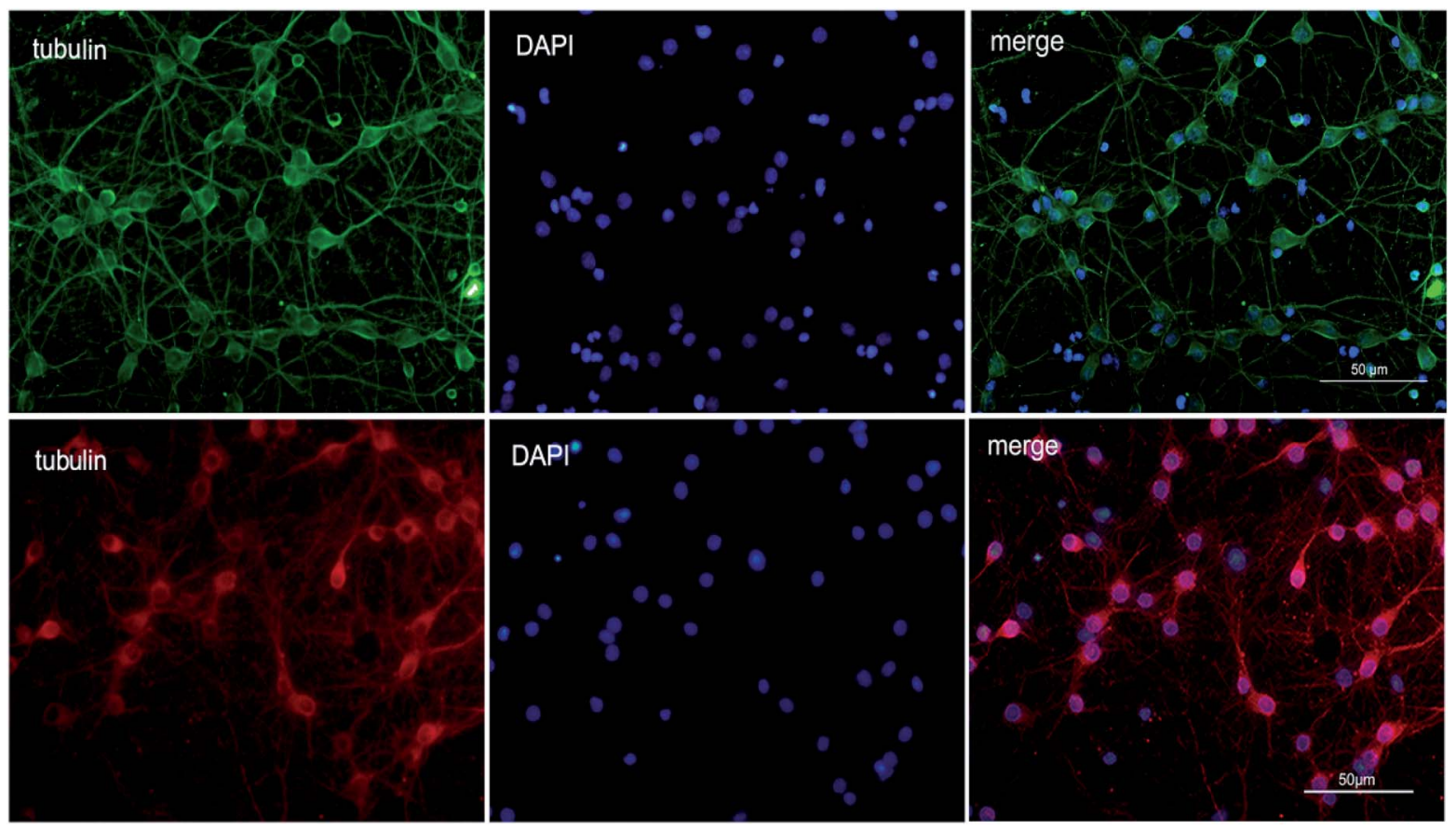

Fig. 2 Purity identification of rat primary cortical neurons.

groups on the benzene ring. When the substituents were replaced with hydroxyl groups, the activity was decreased or disappeared, such as BA-01, BA-04. Interestingly, various aromatic cycles, including pyridine, thiophene, furan and naphthalene, showed different efficacy, and BA-09, replaced with naphthalene, exhibited a better activity which increased survival rate of neuron (ODG model) from $49 \%$ to $57 \%$. BA-09, BA-11, respectively substituted with pyridine, thiophene, maintained the same biological activity. On the contrary, 3(furan-2-yl)acrylamide (BA-10) lost neuroprotective effect. Considering that series compounds of BA didn't significantly improve the survival rate of neurons, and we, therefore, designed and synthesized a novel series of 2,2-dimethylbenzopyran derivatives using functional reversal group of $\alpha, \beta$-unsaturated amide group to afford $\mathrm{BN}$ compounds.
To our excitement, the cell viability results suggested that series compounds of BN can obviously increase the survival rate of neurons (OGD $12 \mathrm{~h}$ ) at dose of $1 \mu \mathrm{M}, 30 \mu \mathrm{M}$ and $100 \mu \mathrm{M}$ which were much superior to positive drug of edaravone (56\%), compared with model group. $(P<0.001)$ (Table 3 , and ESI, Fig. S3†). Experimental data demonstrated that activity was greatly increased when aniline substituted with methoxy such as BN-02, 03, 04, and the survival rate of neurons were 87\%, 87\%, 83\% respectively, compared with BN-01 (73\%). Moreover, the meta and para substituted compounds were more potent than the ortho. Attempt to replace aniline with phenol proved successful which displayed $81 \%$ survival rate of neuron (BN-05). Inspired by neuroprotective effects of cinnamamide derivatives, ${ }^{32,33}$ we synthesized amide with $N$ substituted piperazine showing superior biological activity.

Table 1 Cell survival rate of primary neurons after administration (\%) $)^{a, b}$

\begin{tabular}{|c|c|c|c|c|c|}
\hline Sample & Control & $100 \mu \mathrm{M}$ & Sample & Control & $100 \mu \mathrm{M}$ \\
\hline BA-01 & $1.00 \pm 0.015$ & $0.75 \pm 0.021^{* * *}$ & BN-01 & $1.00 \pm 0.011$ & $0.85 \pm 0.038^{* *}$ \\
\hline BA-02 & $1.00 \pm 0.015$ & $0.76 \pm 0.025^{* * *}$ & BN-02 & $1.00 \pm 0.011$ & $0.93 \pm 0.0080$ \\
\hline BA-04 & $1.00 \pm 0.015$ & $0.56 \pm 0.014^{* * *}$ & BN-04 & $1.00 \pm 0.011$ & $0.88 \pm 0.038$ \\
\hline BA-05 & $1.00 \pm 0.011$ & $0.85 \pm 0.037^{* *}$ & BN-05 & $1.00 \pm 0.011$ & $0.86 \pm 0.023^{*}$ \\
\hline BA-06 & $1.00 \pm 0.011$ & $0.86 \pm 0.018^{*}$ & BN-06 & $1.00 \pm 0.011$ & $0.91 \pm 0.028$ \\
\hline BA-09 & $1.00 \pm 0.011$ & $0.49 \pm 0.047^{* * *}$ & BN-09 & $1.00 \pm 0.011$ & $0.80 \pm 0.047^{* * *}$ \\
\hline BA-10 & $1.00 \pm 0.011$ & $0.84 \pm 0.026^{* *}$ & $\mathrm{BN}-10$ & $1.00 \pm 0.011$ & $0.81 \pm 0.058^{* * *}$ \\
\hline BA-11 & $1.00 \pm 0.011$ & $0.89 \pm 0.054$ & & & \\
\hline
\end{tabular}

${ }^{a}$ Significance: ${ }^{*} P<0.05,{ }^{* *} P<0.01,{ }^{* * *} P<0.001$ vs. control group. ${ }^{b}$ The dose of administration was $100 \mu \mathrm{M}$ and data were expressed as mean \pm standard error (SE). 
Table 2 Cell survival rate of primary neurons (OGD $12 \mathrm{~h}$ ) after administration in BA compounds (\%)

\begin{tabular}{|c|c|c|c|c|c|c|}
\hline Sample & Control & Model & Sample in $1 \mu \mathrm{M}$ & Sample in $30 \mu \mathrm{M}$ & Sample in $100 \mu \mathrm{M}$ & Edaravone $^{d}$ \\
\hline BA-01 & $1.00 \pm 0.012$ & $0.49 \pm 0.094^{\# \# \#}$ & $0.52 \pm 0.023$ & $0.28 \pm 0.040^{* * *}$ & $-^{c}$ & $0.54 \pm 0.0069^{*}$ \\
\hline BA-02 & $1.00 \pm 0.012$ & $0.49 \pm 0.094^{\# \# \#}$ & $0.42 \pm 0.024 * *$ & $0.30 \pm 0.046^{* * *}$ & $-^{c}$ & $0.54 \pm 0.0069 *$ \\
\hline BA-04 & $1.00 \pm 0.012$ & $0.49 \pm 0.094^{\# \# \#}$ & $0.42 \pm 0.054^{*}$ & $0.23 \pm 0.019^{* * *}$ & $-^{c}$ & $0.54 \pm 0.0069^{*}$ \\
\hline BA-05 & $1.00 \pm 0.012$ & $0.49 \pm 0.094^{\# \# \#}$ & $0.56 \pm 0.027^{*}$ & $0.40 \pm 0.012^{* * *}$ & $0.29 \pm 0.013^{* * *}$ & $0.54 \pm 0.0069 *$ \\
\hline BA-06 & $1.00 \pm 0.012$ & $0.49 \pm 0.094^{\# \# \#}$ & $0.50 \pm 0.040$ & $0.33 \pm 0.032^{* * *}$ & $0.37 \pm 0.068^{* *}$ & $0.54 \pm 0.0069^{*}$ \\
\hline BA-09 & $1.00 \pm 0.012$ & $0.49 \pm 0.094^{\# \# \#}$ & $0.54 \pm 0.028^{*}$ & $0.29 \pm 0.011^{* * *}$ & $-c$ & $0.54 \pm 0.0069^{*}$ \\
\hline BA-10 & $1.00 \pm 0.012$ & $0.49 \pm 0.094^{\# \# \#}$ & $0.46 \pm 0.025$ & $0.25 \pm 0.0017^{* * *}$ & $0.19 \pm 0.0017^{* * *}$ & $0.54 \pm 0.0069^{*}$ \\
\hline BA-11 & $1.00 \pm 0.012$ & $0.49 \pm 0.094^{\# \# \#}$ & $0.56 \pm 0.022 *$ & $0.25 \pm 0.021 * * *$ & $0.21 \pm 0.0023 * * *$ & $0.54 \pm 0.0069 *$ \\
\hline
\end{tabular}

${ }^{a}$ Significance: ${ }^{\# \#} P<0.001$ vs. control group. Significance: ${ }^{*} P<0.05,{ }^{*} P<0.01,{ }^{* * *} P<0.001$ vs. model group. ${ }^{b}$ Data were expressed as mean \pm standard error (SE). ${ }^{c}$ At this concentration, the compound was cytotoxic. ${ }^{d}$ The concentration was $100 \mu \mathrm{M}$.

Among them, BN-07, substituted with 4-(piperazin-1-yl) phenol, increased the survival rate of neuron from $41 \%$ to 98\%. Correspondingly, BN-06, substituted with 1-(4-methoxyphenyl)piperazine, maintained the similar activity (75\%), which indicated that hydrophile group of 1-phenylpiperazine was contributed to neuroprotective effect. Interestingly, three compounds without double bonds $(\mathrm{BN}-\mathbf{0 8}, \mathbf{0 9}, \mathbf{1 0})$ maintained good biological activity which increased the survival rates of neuron to more than $80 \%$. The results demonstrated that the $\alpha, \beta$-unsaturated double bond isn't essential for the activity. Based on the neuroprotective activities in vitro shown in Tables 2 and 3, it was observed that series of compounds BN revealed better pharmaceutical effects of neuroprotection which were suitable for further research of anti-ischemic stroke.

2.2.3 The morphological changes of neurons after administration. Then, we evaluated the morphological changes of cortical neuron which were observed with an inverted microscope. The results were as follows, and other pictures of different doses were placed in ESI (Fig. S4). $\uparrow$ Control group indicated that neurons were evenly distributed and cell body took on plumpness, oval or multipole. The axons and dendrites were long and interacting into networks. Apparently, compared with control group, the cell bodies of model group (OGD $12 \mathrm{~h}$ )

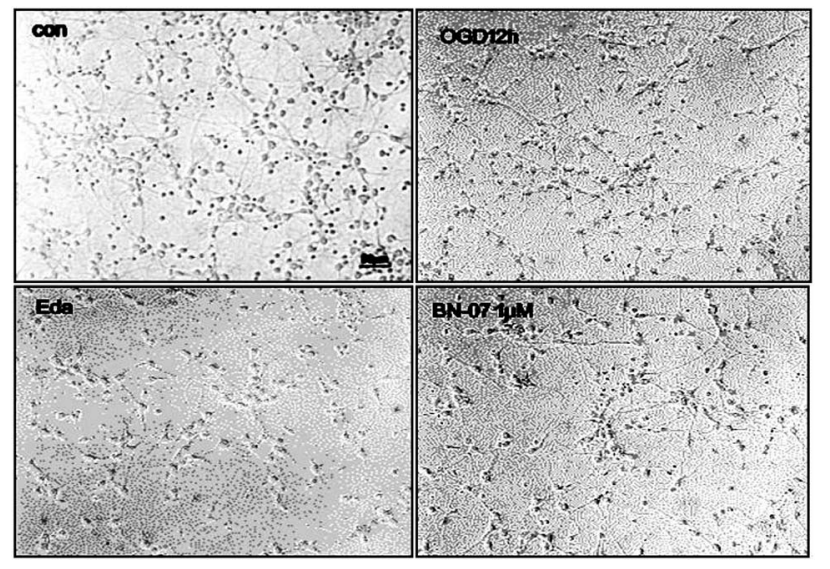

Fig. 3 Morphology of OGD neurons after administration of BN-07.

were obviously shrunk, axons and dendrites were shortened or even disappeared. Surprisingly, excellent results emerged from testing group which restored the morphology of the OGD neurons presenting the plumpness cell and continuous protrusions (Fig. 3). That also reflected a significant role in antiischemic stroke of compounds which was consistent with the results of cell viability.

Table 3 Cell survival rate of primary neurons (OGD $12 \mathrm{~h}$ ) after administration in BN compounds (\%) ${ }^{a, b}$

\begin{tabular}{|c|c|c|c|c|c|c|}
\hline Sample & Control & Model & Sample in $1 \mu \mathrm{M}$ & Sample in $30 \mu \mathrm{M}$ & Sample in $100 \mu \mathrm{M}$ & Edaravone $^{d}$ \\
\hline $\mathrm{BN}-01$ & $1.00 \pm 0.0051$ & $0.41 \pm 0.014^{\# \# \#}$ & $0.73 \pm 0.067^{* * *}$ & $0.67 \pm 0.044^{* * *}$ & $0.60 \pm 0.012^{* * *}$ & $0.56 \pm 0.015^{* * *}$ \\
\hline $\mathrm{BN}-02$ & $1.00 \pm 0.0051$ & $0.41 \pm 0.014^{\# \# \#}$ & $0.87 \pm 0.013^{* * *}$ & $0.74 \pm 0.012^{* * *}$ & $0.50 \pm 0.025^{* * *}$ & $0.56 \pm 0.015^{* * *}$ \\
\hline BN-03 & $1.00 \pm 0.0051$ & $0.41 \pm 0.014^{\# \# \#}$ & $0.87 \pm 0.0084^{* * *}$ & $0.77 \pm 0.0016^{* * *}$ & $0.58 \pm 0.0090^{* * *}$ & $0.56 \pm 0.015^{* * *}$ \\
\hline BN-04 & $1.00 \pm 0.0051$ & $0.41 \pm 0.014^{\# \# \#}$ & $0.83 \pm 0.012^{* * *}$ & $0.73 \pm 0.0066^{* * *}$ & $0.41 \pm 0.064$ & $0.56 \pm 0.015^{* * *}$ \\
\hline BN-05 & $1.00 \pm 0.0051$ & $0.41 \pm 0.014^{\# \# \#}$ & $0.81 \pm 0.010^{* * *}$ & $0.73 \pm 0.0091 * * *$ & $0.69 \pm 0.017^{* * *}$ & $0.56 \pm 0.015^{* * *}$ \\
\hline BN-06 & $1.00 \pm 0.0051$ & $0.41 \pm 0.014^{\# \# \#}$ & $0.75 \pm 0.014^{* * *}$ & $0.77 \pm 0.018^{* * *}$ & $0.70 \pm 0.035^{* * *}$ & $0.56 \pm 0.015^{* * *}$ \\
\hline BN-07 & $1.00 \pm 0.0051$ & $0.41 \pm 0.014^{\# \# \#}$ & $0.98 \pm 0.029^{* * *}$ & $0.83 \pm 0.013^{* * *}$ & $0.66 \pm 0.032^{* * *}$ & $0.56 \pm 0.015^{* * *}$ \\
\hline BN-08 & $1.00 \pm 0.0051$ & $0.41 \pm 0.014^{\# \# \#}$ & $0.89 \pm 0.014 * * *$ & $0.79 \pm 0.017^{* * *}$ & $0.69 \pm 0.015^{* * *}$ & $0.56 \pm 0.015^{* * *}$ \\
\hline BN-09 & $1.00 \pm 0.0051$ & $0.41 \pm 0.014^{\# \# \#}$ & $0.85 \pm 0.015^{* * *}$ & $0.77 \pm 0.010^{* * *}$ & $-{ }^{c}$ & $0.56 \pm 0.015^{* * *}$ \\
\hline $\mathrm{BN}-10$ & $1.00 \pm 0.0051$ & $0.41 \pm 0.014^{\# \# \#}$ & $0.81 \pm 0.0090^{* * *}$ & $0.77 \pm 0.0035^{* * *}$ & $-^{c}$ & $0.56 \pm 0.015^{* * *}$ \\
\hline
\end{tabular}

${ }^{a}$ Significance: ${ }^{\# \#} P<0.001$ vs. control group. Significance: ${ }^{*} P<0.05,{ }^{*} P<0.01,{ }^{* * *} P<0.001$ vs. model group. ${ }^{b}$ Data were expressed as mean \pm standard error (SE). ${ }^{c}$ At this concentration, the compound was cytotoxic. ${ }^{d}$ The concentration was $100 \mu \mathrm{M}$. 
Table 4 Prediction of BBB and clog $P$ properties

\begin{tabular}{lrllll}
\hline Sample & \multicolumn{1}{c}{ BBB $^{a}$} & $\operatorname{clog} P$ & Sample & BBB $^{a}$ & $\operatorname{clog}$ \\
\hline BA-01 & 0.020 & 3.627 & BN-01 & 0.424 & 3.869 \\
BA-02 & -0.126 & 3.611 & BN-02 & 0.278 & 3.853 \\
BA-03 & -0.126 & 3.611 & BN-03 & 0.278 & 3.853 \\
BA-04 & -0.384 & 3.385 & BN-04 & 0.278 & 3.853 \\
BA-05 & 0.070 & 3.638 & BN-05 & 0.686 & 4.517 \\
BA-06 & 0.278 & 3.853 & BN-06 & 0.454 & 4.112 \\
BA-07 & 0.424 & 3.869 & BN-07 & 0.197 & 3.886 \\
BA-08 & 0.705 & 4.778 & BN-08 & 0.547 & 4.992 \\
BA-09 & -0.110 & 2.719 & BN-09 & 0.677 & 5.600 \\
BA-10 & 0.039 & 3.265 & BN-10 & 0.254 & 4.89 \\
BA-11 & 0.340 & 3.595 & & &
\end{tabular}

${ }^{a} \mathrm{BBB} \geq 0.7$, very high permeability; $0 \leq \mathrm{BBB}<0.7$, high permeability; $-0.52<\mathrm{BBB}<0$, medium permeability; $\mathrm{BBB} \leq-0.52$, low permeability.

\subsection{Prediction of ADMET properties}

BBB penetrations of all compounds were predicted by Discovery Studio 3.0 (see ESI, Fig. S5† and Table 4). The ADMET plot figure displayed that most target compounds had potent permeability of blood brain barrier (BBB) and appropriate values of $\operatorname{clog} P$ which were conducive to the development of neuroprotective effect. Among them, BN compounds revealed higher permeability of blood brain barrier than BA compounds. Therefore, predicted data manifested that $\mathrm{BN}$ compounds have the potential to exhibit better activity of neuroprotective in vivo.

\section{Conclusion}

A novel series of 2,2-dimethylbenzopyran derivatives was created from an initial 2,2-dimethyl-2 $H$-chromen-6-amine lead using the molecular hybridization approach, bioisostere and functional group reversal strategies. Subsequently, their activity of neuroprotection was evaluated in oxygen glucose deprivation (OGD) model. Experimental results revealed that some novel compounds exhibit better activity of neuroprotection than edaravone. The efficacy improvement was achieved via lead transformation of cinnamamide to phenylacrylamide and by the incorporation of substituent at the amide position. These efforts culminated with the identification of an optimized molecule, compound BN-07, which displayed good efficacy in neurons of OGD model and will be further optimized as a lead compound. Efforts to determine the neuroprotection mechanism of these compounds are currently under way in our laboratory.

\section{Experimental section}

\subsection{Chemistry}

All reagents used were commercially available. All the ${ }^{1} \mathrm{H}-\mathrm{NMR}$ and ${ }^{13} \mathrm{C}-\mathrm{NMR}$ spectra were recorded on a Bruker $400 \mathrm{MHz}$ and $600 \mathrm{MHz}$ spectrometer in DMSO- $d_{6}$. Chemical shifts $(\delta)$ were expressed in parts per million using tetramethylsilane as an internal reference. ESI-MS data were obtained using an Agilent 1100 instrument. LC-MS-ESI was recorded by Agilent 1100 Series MSD Trap (SL). GC-MS-ESI was recorded by Agilent 6890-
5975 GC-MS. Melting points were measured on X-4 digital melting point instrument. The purity was determined by Shimadzu LC-2010AHT high performance liquid chromatography. Reactions were monitored by thin-layer chromatography (TLC) and visualized by UV-light. Column chromatography was performed on silica gel (160-200 mesh).

4.1.1 3-Chloro-3-methylbut-1-yne (3). To a solution of $\mathrm{CuCl}$ (2.0 g, $0.02 \mathrm{~mol})$, copper powder $(1.12 \mathrm{~g}, 17.6 \mathrm{mmol})$ in concentrated hydrochloric acid $(240 \mathrm{~mL}, 2.91 \mathrm{~mol})$ were added $\mathrm{CaCl}_{2}$ powder $(50 \mathrm{~g}, 0.45 \mathrm{~mol})$ in portions at $-15{ }^{\circ} \mathrm{C}$. The 2 methylbut-3-yn-2-ol $2(50 \mathrm{~mL}, 0.51 \mathrm{~mol})$ was added dropwise at $-15{ }^{\circ} \mathrm{C}$. The reaction mixture was stirred at $0{ }^{\circ} \mathrm{C}$ for $2 \mathrm{~h}$. The upper organic layer was separated, washed with brine $(10 \mathrm{~mL})$, and dried over $\mathrm{CaCl}_{2}$. Filtration afforded the colorless liquid (49.9 g, 94.8\%). EI-MS $m / z: 103.0[\mathrm{M}+\mathrm{H}]^{+}, 67.1[\mathrm{M}-\mathrm{Cl}]^{-}$.

4.1.2 $N$-(4-((2-Methylbut-3-yn-2-yl)oxy)phenyl)acetamide (7) To a solution of $\mathrm{CuCl}(0.08 \mathrm{~g}, 0.80 \mathrm{mmol}), N$-(4-hydroxyphenyl) acetamide $6(22.6 \mathrm{~g}, 0.15 \mathrm{~mol})$ in acetonitrile $(240 \mathrm{~mL})$ were added dropwise DBU (54.2 mL, $0.36 \mathrm{~mol}$ ) at $0{ }^{\circ} \mathrm{C}$. Then the 3-chloro-3methylbut-1-yne 3 (22.9 g, $0.23 \mathrm{~mol})$ was added dropwise. The reaction mixture was stirred at room temperature for $3 \mathrm{~h}$. The acetonitrile was removed in vacuo, and the resulting residue was dissolved with dichloromethane $(300 \mathrm{~mL})$, respectively washed with water $(3 \times 100 \mathrm{~mL})$, brine $(100 \mathrm{~mL})$ and dried over $\mathrm{Na}_{2} \mathrm{SO}_{4}$. Concentration afforded the yellow solid (28.8 g, 88.4\%), mp 83$86{ }^{\circ} \mathrm{C}$. ESI-MS $m / z: 218.1[\mathrm{M}+\mathrm{H}]^{+}$.

4.1.3 $N$-(2,2-Dimethyl-2H-chromen-6-yl)acetamide (8). $\mathrm{N}$ (4-((2-Methylbut-3-yn-2-yl)oxy)phenyl)acetamide 7 (21.8 g, 0.10 $\mathrm{mol})$ was dissolved in diphenyl ether $(80 \mathrm{~mL})$, and the mixture was placed in a sand bath at $260^{\circ} \mathrm{C}$ for $2 \mathrm{~h}$. After cooling to room temperature, the crude product was obtained by flash chromatography (petroleum ether/ethyl acetate $=2: 1$ ), which was recrystallized from absolute ethanol to give the light yellow solid (10.3 g, 47.3\%), mp 116-119 ${ }^{\circ} \mathrm{C}$. ESI-MS $m / z: 218.1[\mathrm{M}+$ $\mathrm{H}]^{+}, 240.1[\mathrm{M}+\mathrm{Na}]^{+}, 435.2[2 \mathrm{M}+\mathrm{H}]^{+}, 457.2[2 \mathrm{M}+\mathrm{Na}]^{+}$.

4.1.4 2,2-Dimethyl-2H-chromen-6-amine (9). To a solution of $\mathrm{N}$-(2,2-dimethyl-2H-chromen-6-yl)acetamide 8 (10.3 g, 47.4 $\mathrm{mmol})$ in $95 \%$ ethanol $(42 \mathrm{~mL})$ were added $50 \% \mathrm{NaOH}(11.4 \mathrm{~mL}$, $0.14 \mathrm{~mol}$ ). The reaction mixture was heated to reflux for $12 \mathrm{~h}$. The ethanol was removed in vacuo, and the resulting residue was partitioned between dichloromethane $(100 \mathrm{~mL})$ and water $(50 \mathrm{~mL})$ and the aqueous was extracted with dichloromethane $(2 \times 50 \mathrm{~mL})$. The combined organic phase was washed with brine $(100 \mathrm{~mL})$, dried over sodium sulfate, and concentrated under vacuum to give 2,2-dimethyl-2 $H$-chromen-6-amine as a brown oil (7.6 g, 92.1\%). ESI-MS $m / z: 176.1[\mathrm{M}+\mathrm{H}]^{+}$.

4.1.5 4-((2-Methylbut-3-yn-2-yl)oxy)benzaldehyde (11). To a solution of $\mathrm{CuCl}(0.05 \mathrm{~g}, 0.5 \mathrm{mmol})$, 4-hydroxybenzaldehyde 10 $(12 \mathrm{~g}, 98.3 \mathrm{mmol})$ in acetonitrile $(120 \mathrm{~mL})$ were added dropwise DBU $(35.5 \mathrm{~mL}, 0.24 \mathrm{~mol})$ at $0{ }^{\circ} \mathrm{C}$. Then the 3-chloro-3-methylbut1-yne 3 (15.1 g, $0.15 \mathrm{~mol})$ was added dropwise. The reaction mixture was stirred at room temperature for $4 \mathrm{~h}$. The acetonitrile was removed in vacuo, and the resulting residue was dissolved with dichloromethane $(100 \mathrm{~mL})$, respectively washed with water $(3 \times 50 \mathrm{~mL})$, brine $(30 \mathrm{~mL})$ and dried over $\mathrm{Na}_{2} \mathrm{SO}_{4}$. Concentration afforded the yellow oil (15.8 g, 85.8\%). ESI-MS $\mathrm{m} /$ $z: 189.1[\mathrm{M}+\mathrm{H}]^{+}, 211.0[\mathrm{M}+\mathrm{Na}]^{+}, 399.1[2 \mathrm{M}+\mathrm{Na}]^{+}$. 
4.1.6 2,2-Dimethyl-2H-chromene-6-carbaldehyde (12). 4((2-Methylbut-3-yn-2-yl)oxy)benzaldehyde 11 (15.0 g, $0.08 \mathrm{~mol})$ was dissolved in $N, N$-dimethylaniline $(40 \mathrm{~mL})$, and the mixture was placed in a sand bath at $200{ }^{\circ} \mathrm{C}$ for $2 \mathrm{~h}$. After cooling to room temperature, the mixture was poured into $6 \mathrm{~N} \mathrm{HCl}(100 \mathrm{~mL})$, stirred for $15 \mathrm{~min}$ and extracted with EtOAc $(4 \times 100 \mathrm{~mL})$. The combined organic phrase was washed with $10 \% \mathrm{HCl}(3 \times 100$ $\mathrm{mL})$ and brine $(50 \mathrm{~mL})$. The organic phase was dried over sodium sulfate and concentrated under vacuum to give the yellow oil (12.1 g, 80.6\%). ESI-MS $m / z: 189.1[\mathrm{M}+\mathrm{H}]^{+}, 211.1[\mathrm{M}+$ $\mathrm{Na}]^{+}, 399.1[2 \mathrm{M}+\mathrm{Na}]^{+}$.

4.1.7 (E)-3-(2,2-Dimethyl-2H-chromen-6-yl)acrylic acid (13). To a solution of 2,2-dimethyl- $2 H$-chromene-6-carbaldehyde aromatic aldehyde 12 (12.1 g, $64.3 \mathrm{mmol})$, malonic acid $(10.0 \mathrm{~g}, 96.1 \mathrm{mmol})$, toluene $(50 \mathrm{~mL})$ in pyridine $(28 \mathrm{~mL})$ were added piperidine $(1.8 \mathrm{~mL}, 20.0 \mathrm{mmol})$. The reaction mixture was heated at $110{ }^{\circ} \mathrm{C}$ with a Dean-Stark trap for $14 \mathrm{~h}$. After cooling to room temperature, $25 \% \mathrm{~K}_{2} \mathrm{CO}_{3}$ aqueous $(50 \mathrm{~mL}, 90.6$ mmol) was poured into the mixture, which was heated at $85{ }^{\circ} \mathrm{C}$ for $30 \mathrm{~min}$. The aqueous layer was separated while it's hot and stirred at $0{ }^{\circ} \mathrm{C}$ for $10 \mathrm{~min}$. The $\mathrm{pH}$ was adjusted to 1 with concentrated hydrochloric acid. The resulting precipitate was filtered, and the filter cake was washed with water. After drying, the crude product was obtained which was purified by recrystallized (absolute ethanol) and decolorized (activated carbon).

(E)-3-(2,2-Dimethyl-2H-chromen-6-yl)acrylic acid 13 was obtained as a light yellow solid $(7.41 \mathrm{~g}, 50.1 \%), \mathrm{mp} 181-184{ }^{\circ} \mathrm{C} .{ }^{1} \mathrm{H}-$ NMR (400 MHz, DMSO- $\left.d_{6}\right): \delta(\mathrm{ppm}) 12.24(\mathrm{~s}, 1 \mathrm{H}), 7.48(\mathrm{~d}, J=$ $15.6 \mathrm{~Hz}, 1 \mathrm{H}), 7.44-7.41(\mathrm{~m}, 2 \mathrm{H}), 6.76$ (d, $J=8.0 \mathrm{~Hz}, 1 \mathrm{H}), 6.42$ (d, $J=9.9 \mathrm{~Hz}, 1 \mathrm{H}), 6.34(\mathrm{~d}, J=15.6 \mathrm{~Hz}, 1 \mathrm{H}), 5.81(\mathrm{~d}, J=9.9 \mathrm{~Hz}, 1 \mathrm{H})$, $1.39(\mathrm{~s}, 6 \mathrm{H})$.

4.1.8 General procedure for the synthesis of $5 \mathrm{a}, 5 \mathrm{c}, 5 \mathrm{e}, 5 \mathrm{f}$, $\mathbf{5 h}, \mathbf{5 i}, \mathbf{5 k}$. To a solution of aromatic aldehyde ( 1 equiv.), malonic acid ( 1.5 equiv.), toluene $(3 \mathrm{v} / \mathrm{m})$ in pyridine $(5 \mathrm{v} / \mathrm{m})$ were added piperidine ( 0.25 equiv.). The reaction mixture was heated at $110{ }^{\circ} \mathrm{C}$ with a Dean-Stark trap for $12 \mathrm{~h}$. After cooling to room temperature, $25 \% \quad \mathrm{~K}_{2} \mathrm{CO}_{3}$ aqueous (25 mL, 1.1 equiv.) was poured into the mixture, which was heated at $85{ }^{\circ} \mathrm{C}$ for $15 \mathrm{~min}$. The aqueous layer was separated while it's hot and stirred at $0{ }^{\circ} \mathrm{C}$ for $10 \mathrm{~min}$. The $\mathrm{pH}$ was adjusted to 1 with concentrated hydrochloric acid. The resulting precipitate was filtered, and the filter cake was washed with water. After drying, the crude product was obtained which was purified by recrystallized (absolute ethanol) and decolorized (activated carbon).

(E)-3-(4-Hydroxyphenyl)acrylic acid (5a). 5a was obtained as a light yellow solid in $30.4 \%$ yield, mp $212-214{ }^{\circ} \mathrm{C}$.

(E)-3-(3-Hydroxy-4-methoxyphenyl)acrylic acid (5c). 5c was obtained as a light yellow solid in $78.4 \%$ yield, mp $123-125{ }^{\circ} \mathrm{C}$.

(E)-3-(Benzo[d][1,3]dioxol-5-yl)acrylic acid (5e). 5e was obtained as a light yellow solid in $80.7 \%$ yield, mp $242-244{ }^{\circ} \mathrm{C}$.

(E)-3-(4-Methoxyphenyl)acrylic acid (5f). 5f was obtained as a light yellow solid in $73.1 \%$ yield, mp $171-173{ }^{\circ} \mathrm{C}$.

(E)-3-(Naphthalen-1-yl)acrylic acid (5h). 5h was obtained as a light yellow solid in 50.3\% yield, mp $210-212{ }^{\circ} \mathrm{C}$.

(E)-3-(Pyridin-3-yl)acrylic acid (5i). 5i was obtained as a white solid in $56.6 \%$ yield, $\mathrm{mp} 235-237^{\circ} \mathrm{C}$.
(E)-3-(Thiophen-2-yl)acrylic acid (5k). 5k was obtained as a light yellow solid in $76.4 \%$ yield, $\mathrm{mp} 144-146{ }^{\circ} \mathrm{C}$.

4.1.9 General procedure for the synthesis of BA-01-05, 0811, 9a-9e, 9h-9k. 1-Ethyl-3-(3-dimethylaminopropyl) carbodiimide hydrochloride (EDCI) $(0.61 \mathrm{~g}, 3.18 \mathrm{mmol}$ ) and 1hydroxybenzotriazole (HOBt) $(0.43 \mathrm{~g}, 3.18 \mathrm{mmol})$ were added to a solution of $(E)$-3-argioacrylic acid $(3.46 \mathrm{mmol})$ in anhydrous tetrahydrofuran $(20 \mathrm{~mL})$. The solution was stirred at room temperature for $1 \mathrm{~h}$, and then 2,2-dimethyl-2H-chromen-6amine 8 (0.5 g, $2.88 \mathrm{mmol})$ was added. The reaction mixture was stirred at room temperature for $14 \mathrm{~h}$. The tetrahydrofuran was removed in vacuo, and the resulting residue was dissolved with dichloromethane $(100 \mathrm{~mL})$, respectively washed with $10 \%$ $\mathrm{HCl}(3 \times 30 \mathrm{~mL})$, saturated $\mathrm{NaHCO}_{3}(3 \times 30 \mathrm{~mL})$ and brine $(50$ $\mathrm{mL}$ ). The organic phase was dried over sodium sulfate and concentrated under vacuum to give crude product which was purified by silica gel column chromatography using petroleum ether : EtOAc $=4: 1$ as eluent.

(E)-N-(2,2-Dimethyl-2H-1-benzopyran-6-yl)-3-(4-hydroxyphenyl)acrylamide (BA-01). BA-01 was isolated as a light yellow solid $(0.21 \mathrm{~g}, 23.0 \%), \mathrm{mp} 230-233{ }^{\circ} \mathrm{C} .{ }^{1} \mathrm{H}-\mathrm{NMR}$ (400 MHz, DMSO- $d_{6}$ ): $\delta(\mathrm{ppm})$ 9.93-9.92 (m, 2H), 7.46-7.42 (m, 4H), 7.35 (dd, $J=$ $8.8 \mathrm{~Hz}, 2.4 \mathrm{~Hz}, 1 \mathrm{H}), 6.81$ (d, $J=8.5 \mathrm{~Hz}, 2 \mathrm{H}), 6.70(\mathrm{~d}, J=8.8 \mathrm{~Hz}$, $1 \mathrm{H}), 6.57(\mathrm{~d}, J=15.6 \mathrm{~Hz}, 1 \mathrm{H}), 6.40(\mathrm{~d}, J=9.8 \mathrm{~Hz}, 1 \mathrm{H}), 5.77(\mathrm{~d}, J=$ $9.8 \mathrm{~Hz}, 1 \mathrm{H}), 1.36(\mathrm{~s}, 6 \mathrm{H}) .{ }^{13} \mathrm{C}$ NMR $\left(150 \mathrm{MHz}, \mathrm{DMSO}-d_{6}\right) \delta 164.1$, $159.6,148.7,140.3,132.2$, 132.1, 129.9, 126.3, 122.4, 121.3, 120.7, 119.2, 117.9, 116.3, 76.3, 27.7. ESI-MS $m / z: 322.1[\mathrm{M}+\mathrm{H}]^{+}$, $643.1[2 \mathrm{M}+\mathrm{H}]^{+}, 665.2[2 \mathrm{M}+\mathrm{Na}]^{+}$.

(E)-N-(2,2-Dimethyl-2H-1-benzopyran-6-yl)-3-(4-hydroxy-3-methoxyphenyl)acrylamide (BA-02). BA-02 was isolated as a light yellow solid (0.30 g, 29.4\%), mp 88-91 ${ }^{\circ} \mathrm{C} .{ }^{1} \mathrm{H}-\mathrm{NMR}\left(400 \mathrm{MHz}, \mathrm{CDCl}_{3}\right): \delta(\mathrm{ppm})$ 7.65 (d, $J=15.6 \mathrm{~Hz}, 1 \mathrm{H}), 7.42$ (s, 1H), 7.16-7.09 (m, 3H), 7.02 (s, $1 \mathrm{H}), 6.92(\mathrm{~d}, J=8.4 \mathrm{~Hz}, 1 \mathrm{H}), 6.77(\mathrm{~d}, J=8.4 \mathrm{~Hz}, 1 \mathrm{H}), 6.37$ (d, $J=$ $15.6 \mathrm{~Hz}, 1 \mathrm{H}), 6.31$ (d, $J=10.0 \mathrm{~Hz}, 1 \mathrm{H}), 5.84(\mathrm{~s}, 1 \mathrm{H}), 5.64$ (d, $J=$ $10.0 \mathrm{~Hz}, 1 \mathrm{H}), 3.93$ (s, 3H), 1.43 (s, 6H). ${ }^{13} \mathrm{C} \mathrm{NMR}\left(150 \mathrm{MHz}, \mathrm{CDCl}_{3}\right.$ ) $\delta 164.1,149.7,148.3,146.7,142.0,131.5,131.2,127.3,123.5,122.3$, 121.6, 120.9, 118.6, 118.5, 116.5, 114.8, 109.8, 76.3, 56.0, 27.9. ESIMS $m / z: 352.2[\mathrm{M}+\mathrm{H}]^{+}, 374.2[\mathrm{M}+\mathrm{Na}]^{+}, 350.4[\mathrm{M}-\mathrm{H}]^{-}$.

(E)-N-(2,2-Dimethyl-2H-1-benzopyran-6-yl)-3-(3-hydroxy-4-methoxyphenyl)acrylamide (BA-03). BA-03 was isolated as a light yellow solid (0.20 g, 19.7\%), mp 185-188 ${ }^{\circ} \mathrm{C} .{ }^{1} \mathrm{H}-\mathrm{NMR}\left(400 \mathrm{MHz}, \mathrm{CDCl}_{3}\right)$ : $\delta(\mathrm{ppm}) 7.62(\mathrm{~d}, J=15.4 \mathrm{~Hz}, 1 \mathrm{H}), 7.45(\mathrm{~s}, 1 \mathrm{H}), 7.42(\mathrm{~s}, 1 \mathrm{H}), 7.19(\mathrm{~d}, J$ $=8.0 \mathrm{~Hz}, 1 \mathrm{H}), 7.13(\mathrm{~s}, 1 \mathrm{H}), 6.98(\mathrm{~d}, J=8.0 \mathrm{~Hz}, 1 \mathrm{H}), 6.80(\mathrm{~d}, J=$ $8.4 \mathrm{~Hz}, 1 \mathrm{H}), 6.73$ (d, $J=8.4 \mathrm{~Hz}, 1 \mathrm{H}), 6.37$ (d, $J=15.4 \mathrm{~Hz}, 1 \mathrm{H}), 6.28$ $(\mathrm{d}, J=9.8 \mathrm{~Hz}, 1 \mathrm{H}), 5.62(\mathrm{~d}, J=9.8 \mathrm{~Hz}, 1 \mathrm{H}), 3.90(\mathrm{~s}, 3 \mathrm{H}), 1.41(\mathrm{~s}, 6 \mathrm{H})$. ${ }^{13} \mathrm{C}$ NMR $\left(150 \mathrm{MHz}, \mathrm{CDCl}_{3}\right) \delta 164.1,149.7,148.2,145.8,141.7$, $131.5,131.3,128.3,2,122.3,121.9,121.5,120.9,119.0,118.6$, 116.5, 120.6, 110.5, 76.3, 56.0, 27.9. ESI-MS $m / z: 352.3[\mathrm{M}+\mathrm{H}]^{+}$, $350.4[\mathrm{M}-\mathrm{H}]^{-}$.

(E)-N-(2,2-Dimethyl-2H-1-benzopyran-6-yl)-3-(3,4-dihydroxyphenyl)acrylamide (BA-04). BA-04 was isolated as a gray solid (0.33 g, 33.9\%), mp 220-222 ${ }^{\circ} \mathrm{C}$. ${ }^{1} \mathrm{H}-\mathrm{NMR}$ (400 MHz, DMSO- $d_{6}$ ): $\delta(\mathrm{ppm}) 9.91(\mathrm{~s}, 1 \mathrm{H}), 9.45(\mathrm{~s}, 1 \mathrm{H}), 9.19(\mathrm{~s}, 1 \mathrm{H}), 7.43(\mathrm{~d}, J=2.3 \mathrm{~Hz}$, $1 \mathrm{H}), 7.37-7.33(\mathrm{~m}, 2 \mathrm{H}), 6.99$ (d, $J=1.8 \mathrm{~Hz}, 1 \mathrm{H}), 6.89$ (dd, $J=$ $8.2 \mathrm{~Hz}, 1.8 \mathrm{~Hz}, 1 \mathrm{H}), 6.77$ (d, $J=8.2 \mathrm{~Hz}, 1 \mathrm{H}), 6.70(\mathrm{~d}, J=8.5 \mathrm{~Hz}$, $1 \mathrm{H}), 6.49(\mathrm{~d}, J=15.6 \mathrm{~Hz}, 1 \mathrm{H}), 6.39(\mathrm{~d}, J=9.8 \mathrm{~Hz}, 1 \mathrm{H}), 5.76(\mathrm{~d}, J=$ 
$9.8 \mathrm{~Hz}, 1 \mathrm{H}), 1.36(\mathrm{~s}, 6 \mathrm{H}) .{ }^{13} \mathrm{C}$ NMR $\left(150 \mathrm{MHz}, \mathrm{DMSO}-d_{6}\right) \delta 164.1$, $148.7,148.1,146.1,140.7,133.2$, 132.2, 126.7, 122.4, 121.3, 121.2, 120.6, 119.0, 117.9, 116.3, 116.2, 114.3, 76.3, 60.2, 28.0. ESI-MS $m / z: 338.1[\mathrm{M}+\mathrm{H}]^{+}, 360.1[\mathrm{M}+\mathrm{Na}]^{+}, 675.3[2 \mathrm{M}+\mathrm{H}]^{+}$, $697.2[2 \mathrm{M}+\mathrm{Na}]^{+}$.

(E)-N-(2,2-Dimethyl-2H-1-benzopyran-6-yl)-3-(1,3-benzodioxole-5yl)acrylamide (BA-05). BA-05 was isolated as a light yellow solid (0.23 g, 22.9\%), mp 151-153 ${ }^{\circ} \mathrm{C} .{ }^{1} \mathrm{H}-\mathrm{NMR}\left(400 \mathrm{MHz}, \mathrm{CDCl}_{3}\right)$ : $\delta(\mathrm{ppm}) 7.64(\mathrm{~d}, J=15.3 \mathrm{~Hz}, 1 \mathrm{H}), 7.42(\mathrm{~s}, 1 \mathrm{H}), 7.16-7.15(\mathrm{~m}, 2 \mathrm{H})$, $7.03-7.02(\mathrm{~m}, 2 \mathrm{H}), 6.81(\mathrm{~d}, J=7.88 \mathrm{~Hz}, 1 \mathrm{H}), 6.74(\mathrm{~d}, J=8.52 \mathrm{~Hz}$, $1 \mathrm{H}), 6.34(\mathrm{~d}, J=15.3 \mathrm{~Hz}, 1 \mathrm{H}), 6.31(\mathrm{~d}, J=9.72 \mathrm{~Hz}, 1 \mathrm{H}), 6.01(\mathrm{~s}$, 2H), $5.64(\mathrm{~d}, J=9.72 \mathrm{~Hz}, 1 \mathrm{H}), 1.43(\mathrm{~s}, 6 \mathrm{H}) .{ }^{13} \mathrm{C}$ NMR $(150 \mathrm{MHz}$, $\left.\mathrm{CDCl}_{3}\right) \delta 164.1,149.7,149.2,148.2,141.6,131.5,131.3,129.1$, 124.1, 122.2, 121.5, 121.0, 119.0, 118.6, 116.5, 108.5, 106.4, 101.5, 76.3, 27.9. ESI-MS $m / z: 350.1[\mathrm{M}+\mathrm{H}]^{+}, 372.1[\mathrm{M}+\mathrm{Na}]^{+}, 699.2$ $[2 \mathrm{M}+\mathrm{H}]^{+}, 721.2[2 \mathrm{M}+\mathrm{Na}]^{+}$.

(E)-N-(2,2-Dimethyl-2H-1-benzopyran-6-yl)-3-(naphthalen-1-yl)acrylamide (BA-08). BA-08 was isolated as a white solid (0.08 g, $7.8 \%), \operatorname{mp} 186-189{ }^{\circ} \mathrm{C} .{ }^{1} \mathrm{H}-\mathrm{NMR}\left(400 \mathrm{MHz}, \mathrm{CDCl}_{3}\right): \delta(\mathrm{ppm}) 8.60$ $(\mathrm{d}, J=15.1 \mathrm{~Hz}, 1 \mathrm{H}), 8.27(\mathrm{~d}, J=8.4 \mathrm{~Hz}, 1 \mathrm{H}), 7.91-7.89(\mathrm{~m}, 2 \mathrm{H})$, 7.77-7.75 (m, 1H), 7.60-7.55 (m, 2H), 7.53-7.50 (m, 2H), 7.24$7.22(\mathrm{~m}, 2 \mathrm{H}), 6.79(\mathrm{~d}, J=8.4 \mathrm{~Hz}, 1 \mathrm{H}), 6.61(\mathrm{~d}, J=15.1 \mathrm{~Hz}, 1 \mathrm{H})$, $6.36(\mathrm{~d}, J=10 \mathrm{~Hz}, 1 \mathrm{H}), 5.68(\mathrm{~d}, J=10.0 \mathrm{~Hz}, 1 \mathrm{H}), 1.46(\mathrm{~s}, 6 \mathrm{H}) \cdot{ }^{13} \mathrm{C}$ NMR (150 MHz, $\mathrm{CDCl}_{3}$ ) $\delta$ 163.7, 149.8, 143.8, 139.2, 133.7, 131.5, $130.9,130.1,128.8,128.6,127.0,126.8,126.2$, 125.4, 123.6, 122.2, 121.6, 121.0, 119.9, 118.6, 116.5, 76.3, 27.9. ESI-MS $m / z$ : $356.1[\mathrm{M}+\mathrm{H}]^{+}, 378.1[\mathrm{M}+\mathrm{Na}]^{+}, 711.3[2 \mathrm{M}+\mathrm{H}]^{+}, 733.3$ $[2 \mathrm{M}+\mathrm{Na}]^{+}$.

(E)-N-(2,2-Dimethyl-2H-1-benzopyran-6-yl)-3-(pyridin-3-yl)acrylamide (BA-09). BA-09 was isolated as a light yellow solid $(0.25 \mathrm{~g}$, 29.4\%), mp 105-107 ${ }^{\circ} \mathrm{C}$. ${ }^{1} \mathrm{H}-\mathrm{NMR}\left(400 \mathrm{MHz}, \mathrm{CDCl}_{3}\right): \delta(\mathrm{ppm})$ $7.50(\mathrm{~d}, J=15.0 \mathrm{~Hz}, 1 \mathrm{H}), 7.46(\mathrm{~s}, 1 \mathrm{H}), 7.42(\mathrm{~s}, 1 \mathrm{H}), 7.16-7.10(\mathrm{~m}$, 2H), 6.75-6.73 (m, 1H), 6.59-6.58 (m, 1H), 6.47 (s, 1H), $6.40(\mathrm{~d}, J$ $=15.0 \mathrm{~Hz}, 1 \mathrm{H}), 6.31(\mathrm{~d}, J=9.8 \mathrm{~Hz}, 1 \mathrm{H}), 5.64(\mathrm{~d}, J=9.8 \mathrm{~Hz}, 1 \mathrm{H})$, $1.43(\mathrm{~s}, 6 \mathrm{H}) .{ }^{13} \mathrm{C} \mathrm{NMR}\left(150 \mathrm{MHz}, \mathrm{CDCl}_{3}\right) \delta 163.0,150.2,150.1$, $148.8,138.0,134.9$, 131.6, 131.0, 130.8, 123.7, 123.4, 122.1, 121.6, 121.0, 118.6, 116.5, 76.4, 27.9. ESI-MS m/z: $296.1[\mathrm{M}+$ $\mathrm{H}]^{+}, 591.2[2 \mathrm{M}+\mathrm{H}]^{+}, 613.2[2 \mathrm{M}+\mathrm{Na}]^{+}$.

(E)-N-(2,2-Dimethyl-2H-1-benzopyran-6-yl)-3-(furan-2-yl)acrylamide (BA-10). BA-10 was isolated as a light yellow solid (0.25 g, 29.4\%), mp 105-107 ${ }^{\circ} \mathrm{C} .{ }^{1} \mathrm{H}-\mathrm{NMR}\left(400 \mathrm{MHz}, \mathrm{CDCl}_{3}\right)$ : $\delta(\mathrm{ppm}) 7.50(\mathrm{~d}, J=15.0 \mathrm{~Hz}, 1 \mathrm{H}), 7.46(\mathrm{~s}, 1 \mathrm{H}), 7.42(\mathrm{~s}, 1 \mathrm{H})$, 7.16-7.10 (m, 2H), 6.75-6.73 (m, 1H), 6.59-6.58 (m, 1H), 6.47 $(\mathrm{s}, 1 \mathrm{H}), 6.40(\mathrm{~d}, J=15.0 \mathrm{~Hz}, 1 \mathrm{H}), 6.31(\mathrm{~d}, J=9.8 \mathrm{~Hz}, 1 \mathrm{H}), 5.64$ (d, $J=9.8 \mathrm{~Hz}, 1 \mathrm{H}), 1.43(\mathrm{~s}, 6 \mathrm{H}) .{ }^{13} \mathrm{C} \mathrm{NMR}\left(150 \mathrm{MHz}, \mathrm{CDCl}_{3}\right)$ $\delta 163.7,151.3,149.7,144.2,131.5,131.2,128.7,122.2,121.6$, $120.9,118.6,118.5,116.5,114.2,112.3,76.3,27.9$. ESI-MS $m / z$ : $296.1[\mathrm{M}+\mathrm{H}]^{+}, 591.2[2 \mathrm{M}+\mathrm{H}]^{+}, 613.2[2 \mathrm{M}+\mathrm{Na}]^{+}$.

(E)-N-(2,2-Dimethyl-2H-1-benzopyran-6-yl)-3-(thiophen-2-yl)acrylamide (BA-11). BA-11 was isolated as a yellow solid $(0.40 \mathrm{~g}$, 46.6\%), mp 125-127 ${ }^{\circ} \mathrm{C} .{ }^{1} \mathrm{H}-\mathrm{NMR}\left(400 \mathrm{MHz}, \mathrm{CDCl}_{3}\right): \delta(\mathrm{ppm}) 7.84$ $(\mathrm{d}, J=15.1 \mathrm{~Hz}, 1 \mathrm{H}), 7.41(\mathrm{~s}, 1 \mathrm{H}), 7.34(\mathrm{~d}, J=5.0 \mathrm{~Hz}, 1 \mathrm{H}), 7.24-$ $7.22(\mathrm{~m}, 2 \mathrm{H}), 7.15(\mathrm{~d}, J=7.4 \mathrm{~Hz}, 1 \mathrm{H}), 7.05-7.03(\mathrm{~m}, 1 \mathrm{H}), 6.74(\mathrm{~d}, J$ $=8.6 \mathrm{~Hz}, 1 \mathrm{H}), 6.34-6.29(\mathrm{~m}, 1 \mathrm{H}), 6.30(\mathrm{~d}, J=9.8 \mathrm{~Hz}, 1 \mathrm{H}), 1.42(\mathrm{~s}$, 6H). ${ }^{13} \mathrm{C}$ NMR (150 MHz, $\mathrm{CDCl}_{3}$ ) $\delta$ 163.6, 149.8, 139.9, 134.5, 131.5, 131.1, 130.6, 128.1, 127.6, 122.2, 121.5, 121.0, 119.8, 118.6,
116.5, 76.3, 27.9. ESI-MS $m / z: 312.1[\mathrm{M}+\mathrm{H}]^{+}, 334.2[\mathrm{M}+\mathrm{Na}]^{+}$, $622.9[2 \mathrm{M}+\mathrm{H}]^{+}, 645.1[2 \mathrm{M}+\mathrm{Na}]^{+}, 310.0[\mathrm{M}-\mathrm{H}]^{-}$.

4.1.10 General procedure for the synthesis of BA-06 and BA-07. To a solution of (E)-3-argioacrylic acid (4.2 mmol), $N, N$ dimethylformamide (2 drops) in anhydrous dichloromethane $(10 \mathrm{~mL})$ were added thionyl chloride $(1.0 \mathrm{~mL}, 16.8 \mathrm{mmol})$. The reaction mixture was heated to reflux for $3 \mathrm{~h}$. After cooling to room temperature, the solvent was removed in vacuo, and the residue was dissolved in anhydrous dichloromethane (5 mL). This intermediate was taken to the next step without further purification. To a solution of 2,2-dimethyl- $2 H$-chromen-6-amine 9 (0.6 g, $3.5 \mathrm{mmol})$, triethylamine $(1 \mathrm{~mL}, 7.2 \mathrm{mmol})$ in anhydrous dichloromethane $(10 \mathrm{~mL})$ were added dropwise solution of (E)-3-argioacryloyl chloride $(4.2 \mathrm{mmol})$ in dichloromethane which was prepared in the previous step at $0{ }^{\circ} \mathrm{C}$. The reaction mixture was stirred at room temperature for $2 \mathrm{~h}$. The reaction mixture was poured into ice water $(20 \mathrm{~mL})$, and extracted with dichloromethane $(2 \times 10 \mathrm{~mL})$. The combined organic phase was respectively washed with $10 \% \mathrm{NaOH}(3 \times 30 \mathrm{~mL}), 10 \% \mathrm{HCl}(3 \times$ $30 \mathrm{~mL}$ ) and brine $(30 \mathrm{~mL})$. The organic phase was dried over sodium sulfate and concentrated under vacuum to give crude product which was purified by silica gel column chromatography using petroleum ether/EtOAc as eluent.

(E)-N-(2,2-Dimethyl-2H-1-benzopyran-6-yl)-3-(4-methoxyphenyl)acrylamide (BA-06). BA-06 was isolated as a white solid $(0.51 \mathrm{~g}$, 43.5\%), mp 173-175 ${ }^{\circ} \mathrm{C} .{ }^{1} \mathrm{H}-\mathrm{NMR}\left(400 \mathrm{MHz}, \mathrm{CDCl}_{3}\right): \delta$ (ppm) $7.68(\mathrm{~d}, J=15.4 \mathrm{~Hz}, 1 \mathrm{H}), 7.47-7.43(\mathrm{~m}, 3 \mathrm{H}), 7.33-7.30(\mathrm{~m}, 1 \mathrm{H})$, $7.17(\mathrm{~d}, J=8.0 \mathrm{~Hz}, 1 \mathrm{H}), 6.88(\mathrm{~d}, J=8.4 \mathrm{~Hz}, 2 \mathrm{H}), 6.74(\mathrm{~d}, J=$ $8.6 \mathrm{~Hz}, 1 \mathrm{H}), 6.39$ (d, $J=15.4 \mathrm{~Hz}, 1 \mathrm{H}), 6.20(\mathrm{~d}, J=9.6 \mathrm{~Hz}, 1 \mathrm{H})$, $5.63(\mathrm{~d}, J=9.6 \mathrm{~Hz}, 1 \mathrm{H}), 3.83(\mathrm{~s}, 3 \mathrm{H}), 1.42(\mathrm{~s}, 6 \mathrm{H}) .{ }^{13} \mathrm{C} \mathrm{NMR}(150$ $\left.\mathrm{MHz}, \mathrm{CDCl}_{3}\right) \delta 164.2,161.0,149.7,141.6,131.5,131.3,129.5$, $127.4,122.3,121.6,120.9,118.6,118.5,116.5,114.3,76.3$, 55.4, 27.7. ESI-MS $m / z: 336.1[\mathrm{M}+\mathrm{H}]^{+}, 671.3[2 \mathrm{M}+\mathrm{H}]^{+}, 693.2$ $[2 \mathrm{M}+\mathrm{Na}]^{+}$.

(E)-N-(2,2-Dimethyl-2H-1-benzopyran-6-yl)-3-phenylacrylamide (BA-07). BA-07 was isolated as a light yellow solid (0.40 g, 32.6\%), mp 154-157 ${ }^{\circ} \mathrm{C} .{ }^{1} \mathrm{H}-\mathrm{NMR}\left(400 \mathrm{MHz}, \mathrm{CDCl}_{3}\right): \delta(\mathrm{ppm}) 7.71-7.76$ (d, $J=15.5 \mathrm{~Hz}, 1 \mathrm{H}), 7.54-7.52(\mathrm{~m}, 2 \mathrm{H}), 7.43$ (s, 1H), 7.39-7.31 $(\mathrm{m}, 3 \mathrm{H}), 7.20-7.16(\mathrm{~m}, 2 \mathrm{H}), 6.75(\mathrm{~d}, J=8.6 \mathrm{~Hz}, 1 \mathrm{H}), 6.41(\mathrm{~d}, J=$ $15.5 \mathrm{~Hz}, 1 \mathrm{H}), 5.96(\mathrm{~d}, J=9.8 \mathrm{~Hz}, 1 \mathrm{H}), 5.64(\mathrm{~d}, J=9.8 \mathrm{~Hz}, 1 \mathrm{H})$, 1.43 (s, 6H). ${ }^{13} \mathrm{C}$ NMR (150 MHz, $\mathrm{CDCl}_{3}$ ) $\delta 163.8,149.8,142.0$, $134.7,131.5$, 131.1, 129.9, 128.9, 127.9, 122.2, 121.6, 121.0, 120.9, 118.6, 116.5, 76.3, 27.9. ESI-MS $m / z: 306.1[\mathrm{M}+\mathrm{H}]^{+}, 328.1$ $[\mathrm{M}+\mathrm{Na}]^{+}, 611.3[2 \mathrm{M}+\mathrm{H}]^{+}, 633.2[2 \mathrm{M}+\mathrm{Na}]^{+}$.

4.1.11 (E)-3-(2,2-Dimethyl-2H-1-benzopyran-6-yl)- $N$-phenylacrylamide (BN-01). 1-Ethyl-3-(3-dimethylaminopropyl) carbodiimide hydrochloride (EDCI) (0.45 g, $2.35 \mathrm{mmol}$ ) and 1hydroxybenzotriazole (HOBt) $(0.32 \mathrm{~g}, 2.35 \mathrm{mmol})$ were added to a solution of (E)-3-(2,2-dimethyl-2H-chromen-6-yl)acrylic acid $(0.50 \mathrm{~g}, 2.17 \mathrm{mmol})$ in anhydrous dichloromethane $(20 \mathrm{~mL})$. The solution was stirred at room temperature for $1 \mathrm{~h}$, and then aniline $(0.27 \mathrm{~g}, 2.82 \mathrm{mmol})$ was added. The reaction mixture was stirred at room temperature for $20 \mathrm{~h}$ and then diluted with water $(20 \mathrm{~mL})$, extracted with dichloromethane $(2 \times 10 \mathrm{~mL})$. The combined organic phase was respectively washed with $10 \% \mathrm{HCl}$ $(3 \times 30 \mathrm{~mL}), 10 \% \mathrm{NaOH}(3 \times 30 \mathrm{~mL})$, and brine $(30 \mathrm{~mL})$. The organic phase was dried over sodium sulfate and concentrated 
under vacuum to give crude product which was purified by silica gel column chromatography using petroleum ether/EtOAc as eluent. BN-01 was isolated as a yellow solid (0.12 g, 18.1\%), mp 148-151 ${ }^{\circ} \mathrm{C} .{ }^{1} \mathrm{H}-\mathrm{NMR}\left(400 \mathrm{MHz}, \mathrm{CDCl}_{3}\right): \delta(\mathrm{ppm}) 7.67$ (d, $J=$ $15.4 \mathrm{~Hz}, 1 \mathrm{H}), 7.61$ (d, $J=6.8 \mathrm{~Hz}, 2 \mathrm{H}), 7.36-7.19(\mathrm{~m}, 4 \mathrm{H}), 7.15-$ $7.10(\mathrm{~m}, 2 \mathrm{H}), 6.76(\mathrm{~d}, J=8.3 \mathrm{~Hz}, 1 \mathrm{H}), 6.39(\mathrm{~d}, J=15.4 \mathrm{~Hz}, 1 \mathrm{H})$, $6.31(\mathrm{~d}, J=9.8 \mathrm{~Hz}, 1 \mathrm{H}), 5.65(\mathrm{~d}, J=9.8 \mathrm{~Hz}, 1 \mathrm{H}), 1.44(\mathrm{~s}, 6 \mathrm{H}) .{ }^{13} \mathrm{C}$ NMR (150 MHz, $\left.\mathrm{CDCl}_{3}\right) \delta 164.4,154.9,142.2,138.2,131.3,129.1$, 129.0, 127.3, 126.2, 124.2, 121.8, 121.3, 119.9, 118.1, 116.8, 77.7, 28.2. ESI-MS $m / z: 306.1[\mathrm{M}+\mathrm{H}]^{+}, 328.1[\mathrm{M}+\mathrm{Na}]^{+}, 611.2[2 \mathrm{M}+$ $\mathrm{H}]^{+}, 633.2[2 \mathrm{M}+\mathrm{Na}]^{+}$.

4.1.12 General procedure for the synthesis of $\mathrm{BN}-02,04,05$, 07-10. To a solution of (E)-3-(2,2-dimethyl-2H-chromen-6-yl) acrylic acid (0.5 g, $2.17 \mathrm{mmol}), N, N$-dimethylformamide (1 drop) in anhydrous dichloromethane $(20 \mathrm{~mL})$ were added thionyl chloride $(0.56 \mathrm{~mL}, 8.68 \mathrm{mmol})$. The reaction mixture was heated to reflux for $30 \mathrm{~min}$. After cooling to room temperature, the solvent was removed in vacuo, and the residue was dissolved in anhydrous dichloromethane $(5 \mathrm{~mL})$. This intermediate was taken to the next step without further purification. To a solution of substituted aniline $(3.5 \mathrm{mmol})$, triethylamine $(1.5 \mathrm{~mL}, 10.8$ $\mathrm{mmol})$ in anhydrous dichloromethane $(20 \mathrm{~mL})$ were added dropwise solution of (E)-3-(2,2-dimethyl-2H-chromen-6-yl) acrylic chloride $(2.2 \mathrm{mmol})$ in dichloromethane which was prepared in the previous step at $0{ }^{\circ} \mathrm{C}$. The reaction mixture was stirred at room temperature for $2 \mathrm{~h}$. The reaction mixture was poured into ice water $(20 \mathrm{~mL})$, and extracted with dichloromethane $(2 \times 10 \mathrm{~mL})$. The combined organic phase was respectively washed with $10 \% \mathrm{HCl}(3 \times 30 \mathrm{~mL}), 10 \% \mathrm{NaHCO}_{3}$ $(3 \times 30 \mathrm{~mL})$, and brine $(30 \mathrm{~mL})$. The organic phase was dried over sodium sulfate and concentrated under vacuum to give crude product which was purified by silica gel column chromatography using petroleum ether/EtOAc as eluent.

(E)-3-(2,2-Dimethyl-2H-1-benzopyran-6-yl)-N-(4-methoxyphenyl)acrylamide (BN-02). BN-02 was isolated as a yellow solid $(0.22 \mathrm{~g}$, $30.2 \%$ ), mp 140-143 ${ }^{\circ} \mathrm{C} .{ }^{1} \mathrm{H}-\mathrm{NMR}\left(400 \mathrm{MHz}, \mathrm{DMSO}-d_{6}\right): \delta(\mathrm{ppm})$ $10.00(\mathrm{~s}, 1 \mathrm{H}), 7.61$ (d, $J=9.0 \mathrm{~Hz}, 2 \mathrm{H}), 7.45$ (d, $J=15.6 \mathrm{~Hz}, 1 \mathrm{H})$, $7.36(\mathrm{dd}, J=8.3 \mathrm{~Hz}, 1.8 \mathrm{~Hz}, 1 \mathrm{H}), 7.33(\mathrm{~d}, J=1.8 \mathrm{~Hz}, 1 \mathrm{H}), 6.90(\mathrm{~d}, J$ $=9.0 \mathrm{~Hz}, 2 \mathrm{H}), 6.80(\mathrm{~d}, J=8.3 \mathrm{~Hz}, 1 \mathrm{H}), 6.63(\mathrm{~d}, J=15.6 \mathrm{~Hz}, 1 \mathrm{H})$, $6.45(\mathrm{~d}, J=9.8 \mathrm{~Hz}, 1 \mathrm{H}), 5.82(\mathrm{~d}, J=9.8 \mathrm{~Hz}, 1 \mathrm{H}), 3.73(\mathrm{~s}, 3 \mathrm{H}), 1.39$ $(\mathrm{s}, 6 \mathrm{H}) .{ }^{13} \mathrm{C}$ NMR $\left(150 \mathrm{MHz}, \mathrm{CDCl}_{3}\right) \delta 164.3,156.4,154.8,141.7$, $131.4,131.3,129.1,127.4,126.1,121.8,121.7,121.3,118.3$, 116.7, 114.2, 77.2, 55.5, 28.2. ESI-MS $m / z: 671.3[2 \mathrm{M}+\mathrm{H}]^{+}, 693.2$ $[2 \mathrm{M}+\mathrm{Na}]^{+}$.

3-(2,2-Dimethyl-2H-1-benzopyran-6-yl)-N-(4-methoxyphenyl)-3((4-methoxyphenyl)amino)propanamide (BN-09). BN-09 was isolated as a white solid $(0.08 \mathrm{~g}, 8.4 \%), \mathrm{mp} 130-133{ }^{\circ} \mathrm{C} .{ }^{1} \mathrm{H}-\mathrm{NMR}$ (400 MHz, DMSO- $\left.d_{6}\right): \delta(\mathrm{ppm}) 9.70(\mathrm{~s}, 1 \mathrm{H}), 7.43(\mathrm{~d}, J=9.0 \mathrm{~Hz}$, $2 \mathrm{H}), 7.12$ (dd, $J=8.2,1.7 \mathrm{~Hz}, 1 \mathrm{H}), 7.06$ (d, $J=1.5 \mathrm{~Hz}, 1 \mathrm{H}), 6.84$ $(\mathrm{d}, J=9.0 \mathrm{~Hz}, 2 \mathrm{H}), 6.64-6.62(\mathrm{~m}, 3 \mathrm{H}), 6.49(\mathrm{~d}, J=8.9 \mathrm{~Hz}, 2 \mathrm{H})$, $6.33(\mathrm{~d}, J=9.8 \mathrm{~Hz}, 1 \mathrm{H}), 5.74(\mathrm{~d}, J=7.9 \mathrm{~Hz}, 1 \mathrm{H}), 5.59$ (d, $J=$ $9.8 \mathrm{~Hz}, 1 \mathrm{H}), 4.67$ (q, $J=14.4,7.3 \mathrm{~Hz}, 1 \mathrm{H}), 3.70(\mathrm{~s}, 3 \mathrm{H}), 3.58$ (s, $3 \mathrm{H}), 2.72(\mathrm{dd}, J=14.2,7.8 \mathrm{~Hz}, 1 \mathrm{H}), 2.58(\mathrm{dd}, J=14.2,6.4 \mathrm{~Hz}$, 1H), 1.32 (s, 6H). ${ }^{13} \mathrm{C}$ NMR (150 MHz, $\left.\mathrm{CDCl}_{3}\right) \delta$ 169.0, 156.5, $153.0,152.3,140.3,134.3,131.0,130.6,126.8,124.2,122.2$, 122.1, 121.4, 116.6, 116.2, 114.8, 114.1, 76.3, 56.6, 55.6, 55.5, 45.2, 28.1, 28.0. ESI-MS $m / z: 459.2[\mathrm{M}+\mathrm{H}]^{+}$.
(E)-3-(2,2-Dimethyl-2H-1-benzopyran-6-yl)-N-(2-methoxyphenyl) acrylamide (BN-04). $\mathrm{BN}-04$ was isolated as a light yellow solid (0.27 g, 37.1\%), mp 115-116 ${ }^{\circ} \mathrm{C} .{ }^{1} \mathrm{H}-\mathrm{NMR}$ (400 MHz, DMSO- $d_{6}$ ): $\delta(\mathrm{ppm}) 10.00(\mathrm{~s}, 1 \mathrm{H}), 7.61(\mathrm{~d}, J=9.0 \mathrm{~Hz}, 2 \mathrm{H}), 7.45(\mathrm{~d}, J=$ $15.6 \mathrm{~Hz}, 1 \mathrm{H}), 7.37(\mathrm{dd}, J=8.4 \mathrm{~Hz}, 1.6 \mathrm{~Hz}, 1 \mathrm{H}), 7.33(\mathrm{~d}, J=1.6 \mathrm{~Hz}$, $1 \mathrm{H}), 6.90(\mathrm{~d}, J=9.0 \mathrm{~Hz}, 2 \mathrm{H}), 6.80(\mathrm{~d}, J=8.4 \mathrm{~Hz}, 1 \mathrm{H}), 6.63(\mathrm{~d}, J=$ $15.6 \mathrm{~Hz}, 1 \mathrm{H}), 6.45(\mathrm{~d}, J=9.8 \mathrm{~Hz}, 1 \mathrm{H}), 5.82(\mathrm{~d}, J=9.8 \mathrm{~Hz}, 1 \mathrm{H})$, $3.73(\mathrm{~s}, 3 \mathrm{H}), 1.40(\mathrm{~s}, 6 \mathrm{H}) .{ }^{13} \mathrm{C} \mathrm{NMR}\left(150 \mathrm{MHz}, \mathrm{CDCl}_{3}\right) \delta 164.1$, $154.8,147.8,141.7,131.3,129.2$, 128.0, 127.5, 126.0, 123.6, $121.8,121.3,121.2,119.9,118.7,116.7,109.8,77.0,55.7,28.2$. ESI-MS $m / z: 336.1[\mathrm{M}+\mathrm{H}]^{+}, 358.1[\mathrm{M}+\mathrm{Na}]^{+}, 671.3[2 \mathrm{M}+\mathrm{H}]^{+}$, $693.3[2 \mathrm{M}+\mathrm{Na}]^{+}$.

(E)-3-(2,2-Dimethyl-2H-1-benzopyran-6-yl)-acrylate-phenyl ester (BN-05). BN-05 was isolated as a white solid (0.25 g, 37.6\%), mp 93-94 ${ }^{\circ} \mathrm{C}$. ${ }^{1} \mathrm{H}-\mathrm{NMR}\left(400 \mathrm{MHz}, \mathrm{CDCl}_{3}\right): \delta(\mathrm{ppm}) 7.77(\mathrm{~d}, J=$ $15.9 \mathrm{~Hz}, 1 \mathrm{H}), 7.42-7.38(\mathrm{~m}, 2 \mathrm{H}), 7.36(\mathrm{dd}, J=8.4 \mathrm{~Hz}, 2.1 \mathrm{~Hz}, 1 \mathrm{H})$, 7.24-7.21 (m, 2H), 7.17-7.15 (m, 2H), 6.80 (d, $J=8.4 \mathrm{~Hz}, 1 \mathrm{H})$, $6.47(\mathrm{~d}, J=15.9 \mathrm{~Hz}, 1 \mathrm{H}), 6.34(\mathrm{~d}, J=9.9 \mathrm{~Hz}, 1 \mathrm{H}), 5.67$ (d, $J=$ $9.9 \mathrm{~Hz}, 1 \mathrm{H}), 1.46(\mathrm{~s}, 6 \mathrm{H}) .{ }^{13} \mathrm{C} \mathrm{NMR}\left(150 \mathrm{MHz}, \mathrm{CDCl}_{3}\right) \delta 165.7$, $155.5,150.9$, 146.3, 131.4, 129.7, 129.4, 126.9, 126.4, 125.6, $121.7,121.6,121.4,116.9,114.4,77.2,28.3$. ESI-MS $m / z: 307.0$ [M $+\mathrm{H}]^{+}, 345.0[\mathrm{M}+\mathrm{Na}]^{+}, 635.7[\mathrm{M}+\mathrm{Na}]^{+}$.

(E)-3-(2,2-Dimethyl-2H-1-benzopyran-6-yl)-1-(4-(4-hydroxyphenyl)piperazin-1-yl)prop-2-en-1-one (BN-07). $\mathrm{BN}-07$ was isolated as a red brown solid (0.04 g, 4.7\%), mp 193-196 ${ }^{\circ} \mathrm{C} .{ }^{1} \mathrm{H}-\mathrm{NMR}(400 \mathrm{MHz}$, DMSO- $\left.d_{6}\right): \delta(\mathrm{ppm}) 8.90(\mathrm{~s}, 1 \mathrm{H}), 7.49-7.46(\mathrm{~m}, 2 \mathrm{H}), 7.42(\mathrm{~d}, J=$ $15.3 \mathrm{~Hz}, 1 \mathrm{H}), 7.13$ (d, $J=15.3 \mathrm{~Hz}, 1 \mathrm{H}), 6.84-6.81(\mathrm{~m}, 2 \mathrm{H}), 6.76$ (d, $J$ $=8.0 \mathrm{~Hz}, 1 \mathrm{H}), 6.67-6.65(\mathrm{~m}, 2 \mathrm{H}), 6.42(\mathrm{~d}, J=10.0 \mathrm{~Hz}, 1 \mathrm{H}), 5.81(\mathrm{~d}$, $J=10.0 \mathrm{~Hz}, 1 \mathrm{H}), 3.81(\mathrm{~s}, 2 \mathrm{H}), 3.68(\mathrm{~s}, 2 \mathrm{H}), 2.95$ (s, $4 \mathrm{H}), 1.38(\mathrm{~s}, 6 \mathrm{H})$. ${ }^{13} \mathrm{C}$ NMR $\left(150 \mathrm{MHz}, \mathrm{CDCl}_{3}\right) \delta 165.9,155.5,154.7,146.3,143.2$, 131.3, 129.7, 129.0, 127.9, 125.9, 122.3, 121.8, 121.3, 118.2, 116.7, 114.4, 113.9, 77.0, 51.0, 49.9, 45.6, 40.0, 28.2. ESI-MS $m / z: 391.2[\mathrm{M}$ $+\mathrm{H}]^{+}, 781.3[2 \mathrm{M}+\mathrm{H}]^{+}$.

3-(2,2-Dimethyl-2H-1-benzopyran-6-yl)-N-phenyl-3-(phenylamino)propanamide (BN-08). $\mathrm{BN}-08$ was isolated as a white solid $(0.14 \mathrm{~g}$, 16.2\%), mp 143-146 ${ }^{\circ} \mathrm{C} .{ }^{1} \mathrm{H}-\mathrm{NMR}\left(400 \mathrm{MHz}, \mathrm{CDCl}_{3}\right): \delta(\mathrm{ppm}) 7.57$ $(\mathrm{m}, 1 \mathrm{H}), 7.33(\mathrm{~d}, J=7.6 \mathrm{~Hz}, 2 \mathrm{H}), 7.28$ (d, $J=7.6 \mathrm{~Hz}, 2 \mathrm{H}), 7.14-7.06$ $(\mathrm{m}, 4 \mathrm{H}), 6.97$ (d, $J=1.9 \mathrm{~Hz}, 1 \mathrm{H}), 6.73-6.69(\mathrm{~m}, 2 \mathrm{H}), 6.62(\mathrm{~d}, J=$ $7.8 \mathrm{~Hz}, 2 \mathrm{H}), 6.23(\mathrm{~d}, J=9.8 \mathrm{~Hz}, 1 \mathrm{H}), 5.58(\mathrm{~d}, J=9.8 \mathrm{~Hz}, 1 \mathrm{H}), 4.85$ $(\mathrm{s}, 1 \mathrm{H}), 4.76(\mathrm{t}, J=6.1 \mathrm{~Hz}, 1 \mathrm{H}), 2.8(\mathrm{~d}, J=6.2 \mathrm{~Hz}, 2 \mathrm{H}), 1.40(\mathrm{~s}, 6 \mathrm{H})$. ${ }^{13} \mathrm{C}$ NMR $\left(150 \mathrm{MHz}, \mathrm{CDCl}_{3}\right) \delta 169.0,152.4,146.4,137.4,134.1$, 131.1, 129.2, 129.0, 126.8, 124.6, 124.2, 122.2, 121.5, 120.3, 118.5, 116.7, 114.4, 76.4, 55.4, 45.5, 28.1, 28.0. ESI-MS $m / z: 399.2[\mathrm{M}+$ $\mathrm{H}]^{+}, 437.1[\mathrm{M}+\mathrm{K}]^{+}, 797.3[2 \mathrm{M}+\mathrm{H}]^{+}$.

3-(2,2-Dimethyl-2H-1-benzopyran-6-yl)-N-(3-methoxyphenyl)-3((3-methoxyphenyl)amino)propenamide (BN-10). BN-10 was isolated as a white solid $(0.22 \mathrm{~g}, 22.1 \%), \mathrm{mp} 145-146{ }^{\circ} \mathrm{C} .{ }^{1} \mathrm{H}-\mathrm{NMR}$ $\left(400 \mathrm{MHz}, \mathrm{CDCl}_{3}\right): \delta(\mathrm{ppm}) 7.50(1 \mathrm{H}, \mathrm{s}), 7.18(\mathrm{t}, J=8.2 \mathrm{~Hz}, 1 \mathrm{H})$, 7.09-7.07 (m, 2H), $7.04(\mathrm{t}, J=8.2 \mathrm{~Hz}, 1 \mathrm{H}), 6.97(\mathrm{~d}, J=2.0 \mathrm{~Hz}$, $1 \mathrm{H}), 6.80(\mathrm{~d}, J=7.9 \mathrm{~Hz}, 1 \mathrm{H}), 6.71(\mathrm{~d}, J=8.2 \mathrm{~Hz}, 1 \mathrm{H}), 6.63(\mathrm{dd}, J$ $=8.2 \mathrm{~Hz}, 2.0 \mathrm{~Hz}, 1 \mathrm{H}), 6.29-6.22(\mathrm{~m}, 3 \mathrm{H}), 6.18(\mathrm{~s}, 1 \mathrm{H}), 5.58(\mathrm{~d}, J$ $=9.8 \mathrm{~Hz}, 1 \mathrm{H}), 4.74(\mathrm{t}, J=6.1 \mathrm{~Hz}, 1 \mathrm{H}), 3.72(\mathrm{~s}, 3 \mathrm{H}), 3.69(\mathrm{~s}, 3 \mathrm{H})$, $2.81(\mathrm{~d}, J=6.1 \mathrm{~Hz}, 2 \mathrm{H}), 1.40(\mathrm{~s}, 6 \mathrm{H}) .{ }^{13} \mathrm{C} \mathrm{NMR}\left(150 \mathrm{MHz}, \mathrm{CDCl}_{3}\right)$ $\delta 168.8,160.6,160.0,152.5,146.7,138.5,133.2,131.1,130.0$, $129.6,127.0,124.4,122.1,121.5,116.7,112.4,110.5,108.0$, $105.9,104.7,101.1,76.6,56.2,55.3,55.1,45.0,28.1,28.0$. ESI- 
MS $m / z: 459.1[\mathrm{M}+\mathrm{H}]^{+}, 481.2[\mathrm{M}+\mathrm{Na}]^{+}, 497.1[\mathrm{M}+\mathrm{K}]^{+}, 457.0$ $[\mathrm{M}-\mathrm{H}]^{-}$.

4.1.13 General procedure for the synthesis of $\mathrm{BN}-03$ and BN-06. To a solution of (E)-3-(2,2-dimethyl-2H-chromen-6-yl) acrylic acid 13 (0.5 g, $2.17 \mathrm{mmol}), N, N$-dimethylformamide (1 drop) in anhydrous dichloromethane $(20 \mathrm{~mL})$ were added oxalyl chloride (1.4 mL, $16.3 \mathrm{mmol}$ ). The solution was stirred at room temperature for $30 \mathrm{~min}$, and the remaining oxalyl chloride was removed in vacuo, and the resulting residue was dissolved with dichloromethane $(10 \mathrm{~mL})$. This intermediate was taken to the next step without further purification. To a solution of substituted aniline $(2.60 \mathrm{mmol})$, triethylamine $(1.5 \mathrm{~mL}, 10.8$ $\mathrm{mmol})$ in anhydrous dichloromethane $(20 \mathrm{~mL})$ were added dropwise solution of (E)-3-(2,2-dimethyl-2H-chromen-6-yl) acrylic chloride $(2.17 \mathrm{mmol})$ in dichloromethane which was prepared in the previous step at $0{ }^{\circ} \mathrm{C}$. The reaction mixture was stirred at room temperature for $2 \mathrm{~h}$. The reaction mixture was poured into ice water $(20 \mathrm{~mL})$, and extracted with dichloromethane $(2 \times 10 \mathrm{~mL})$. The combined organic phase was respectively washed with $10 \% \mathrm{HCl}(3 \times 30 \mathrm{~mL}), 10 \% \mathrm{NaHCO}_{3}$ $(3 \times 30 \mathrm{~mL})$ and brine $(30 \mathrm{~mL})$. The organic phase was dried over sodium sulfate and concentrated under vacuum to give crude product which was purified by silica gel column chromatography using petroleum ether/EtOAc as eluent.

(E)-3-(2,2-Dimethyl-2H-1-benzopyran-6-yl)-N-(3-methoxyphenyl)acrylamide (BN-03). BN-03 was isolated as a yellow brown solid (0.11 g, 15.1\%), mp 145-148 ${ }^{\circ} \mathrm{C} .{ }^{1} \mathrm{H}-\mathrm{NMR}\left(400 \mathrm{MHz}, \mathrm{CDCl}_{3}\right.$ ): $\delta(\mathrm{ppm}) 7.66(\mathrm{~d}, J=15.4 \mathrm{~Hz}, 1 \mathrm{H}), 7.45(\mathrm{~s}, 2 \mathrm{H}), 7.28(\mathrm{~d}, J=8.4 \mathrm{~Hz}$, $1 \mathrm{H}), 7.24(\mathrm{t}, J=8.1 \mathrm{~Hz}, 1 \mathrm{H}), 7.13(\mathrm{~s}, 1 \mathrm{H}), 7.05-7.03(\mathrm{~m}, 1 \mathrm{H}), 6.75$ $(\mathrm{d}, J=8.4 \mathrm{~Hz}, 1 \mathrm{H}), 6.67(\mathrm{~d}, J=8.1 \mathrm{~Hz}, 1 \mathrm{H}), 6.39(\mathrm{~d}, J=15.4 \mathrm{~Hz}$, $1 \mathrm{H}), 6.29$ (d, $J=10.0 \mathrm{~Hz}, 1 \mathrm{H}), 5.65$ (d, $J=10.0 \mathrm{~Hz}, 1 \mathrm{H}), 3.81$ (s, $3 \mathrm{H}), 1.44$ (s, 6H). ${ }^{13} \mathrm{C}$ NMR (150 MHz, $\left.\mathrm{CDCl}_{3}\right) \delta 164.5,160.2$, $154.9,142.3,139.5,131.3,129.7,129.1,127.3,126.2,121.7$, 121.3, 118.1, 116.8, 112.0, 110.3, 105.4, 77.0, 55.3, 28.2. ESI-MS $m / z: 336.1[\mathrm{M}+\mathrm{H}]^{+}, 358.1[\mathrm{M}+\mathrm{Na}]^{+}, 671.3[2 \mathrm{M}+\mathrm{H}]^{+}, 693.3$ $[2 \mathrm{M}+\mathrm{Na}]^{+}$.

(E)-3-(2,2-Dimethyl-2H-1-benzopyran-6-yl)-1-(4-(4-methoxyphenyl)piperazin-1-yl)prop-2-en-1-one (BN-06). BN-06 was isolated as a light yellow solid $(0.27 \mathrm{~g}, 30.8 \%)$, mp $165-166{ }^{\circ} \mathrm{C} .{ }^{1} \mathrm{H}-\mathrm{NMR}$ $\left(400 \mathrm{MHz}, \mathrm{DMSO}-d_{6}\right): \delta(\mathrm{ppm}) 7.49-7.46(\mathrm{~m}, 2 \mathrm{H}), 7.42(\mathrm{~d}, J=$ $15.3 \mathrm{~Hz}, 1 \mathrm{H}), 7.13$ (d, $J=15.3 \mathrm{~Hz}, 1 \mathrm{H}), 6.84-6.81(\mathrm{~m}, 2 \mathrm{H}), 6.85-$ $6.82(\mathrm{~m}, 2 \mathrm{H}), 6.76(\mathrm{~d}, J=8.0 \mathrm{~Hz}, 1 \mathrm{H}), 6.41(\mathrm{~d}, J=10.0 \mathrm{~Hz}, 1 \mathrm{H})$, $5.81(\mathrm{~d}, J=10.0 \mathrm{~Hz}, 1 \mathrm{H}), 3.83(\mathrm{~s}, 2 \mathrm{H}), 3.72-3.68(\mathrm{~m}, 5 \mathrm{H}), 3.01(\mathrm{~s}$, $4 \mathrm{H}), 1.39$ (s, 6H). ${ }^{13} \mathrm{C}$ NMR (150 MHz, $\mathrm{CDCl}_{3}$ ) $\delta$ 165.8, 154.6, $154.4,145.2$, 142.9, 131.3, 129.0, 128.7, 128.0, 125.9, 121.8, $121.3,120.8,119.0,116.7,114.5,114.1,77.0,55.6,51.5,51.0$, 45.9, 42.2, 28.2. ESI-MS $m / z: 405.2[\mathrm{M}+\mathrm{H}]^{+}, 427.2[\mathrm{M}+\mathrm{Na}]^{+}$.

\subsection{In vitro neuroprotection activity}

4.2.1 Materials. Female Sprague Dawley rats (SD Rats), male Sprague Dawley rat were purchased from Liaoning changsheng biotechnology Co., Ltd (Liaoning, China). All animal procedures were performed in accordance with the Guidelines for Care and Use of Laboratory Animals of Shenyang Pharmaceutical University and experiments were approved by the Animal Ethics Committee of Shenyang Pharmaceutical University.
Edaravone injection (30 mg/20 mL) were purchased from simcere Co., Ltd (Jiangsu, China). DMEM/F12 medium, neurobasal medium, B27 supplement, DMEM glucose-free culture medium, penicillin-streptomycin, FBS and Fetal bovine serum were purchased from Gibco Company (USA). L-Lysine homopolymer hydrobromide, thiazolyl blue (MTT), and dimethyl sulfoxide (DMSO) were purchased from Sigma-Aldrich (St. Louis, MO, USA). DAPI was purchased from Dojindo Laboratories (Japan). $\beta$-Tubulin antibody was purchased from Abcam Company (UK).

4.2.2 Preparation of samples. Stock solution of tested compounds were prepared in DMSO at a concentration of $100 \mathrm{mM}$ and diluted to the desired final concentration with neurobasal/B27 medium immediately before use. Final DMSO concentration in all samples was lowered than $0.1 \%$, which had no neuroprotective effect in biological assays. Edaravone injection was diluted to $100 \mu \mathrm{M}$ with medium as a positive drug. ${ }^{34}$

4.2.3 Culture of cortical primary neurons of rats. Rat cortical neurons were prepared from newborn $(24 \mathrm{~h})$ SD rats. After dissected brain cortical tissue were minced, trypsinized $(0.25 \%)$ and mechanically dissociated, cells were seeded into 48 -well plates (adjusted to $1.0 \times 10^{6}$ cells per $\mathrm{mL}$ ) pre-coated with $0.01 \%$ poly-L-lysine, and cultured in neurobasal medium supplemented with $2 \% \mathrm{~B} 27,100 \mathrm{U} \mathrm{mL}^{-1}$ penicillin and $100 \mu \mathrm{g}$ $\mathrm{mL}^{-1}$ streptomycin. After 7 days, the cultured cells could be used according to the experiment design.

4.2.4 Identification of purity about primary neuron. The primary cortical neurons from SD rats were cultured by neurobasal and B27 supplement medium for 7 days. Then the cells were fixed in $4 \%$ paraformaldehyde in $0.1 \mathrm{M}$ PBS for $20 \mathrm{~min}$, permeabilized with $0.03 \%$ Triton X-100 in PBS for 20 min and blocked with $10 \%$ BSA for $1 \mathrm{~h}$ at room temperature. Then, we stained the cells with $\beta$-tubulin III diluted in 0.1 M PBS overnight at $4{ }^{\circ} \mathrm{C}$. After incubation in fluorochrome-coupled secondary antibody for $1 \mathrm{~h}$ at $37^{\circ} \mathrm{C}$, the stained cells were mounted with mounting medium containing DAPI. The molecule probe $\beta$-tubulin III antibody colocalized with the $\beta$-tubulin. Negative control experiment was carried out same procedures which replaced $\beta$-tubulin III antibody with PBS.

4.2.5 In vitro OGD model of neurons. Cultured cortical neurons exposed to oxygen-glucose deprivation (OGD) were used as a hypoxic-ischemic model in vitro. Briefly, isolated cortical neurons were randomly divided into control group, model group, positive control group, and test group $(1 \mu \mathrm{M}, 30$ $\mu \mathrm{M}, 100 \mu \mathrm{M})$. Among them, the positive control group was added with medium containing $100 \mu \mathrm{M}$ of edaravone.

After $24 \mathrm{~h}$ of pretreatment with compounds of interest, the control group was cultured in neurobasal/B27 medium at $37^{\circ} \mathrm{C}$. The model group, positive control group, and test group were conducted with glucose-free DMEM medium before placing them into an anaerobic chamber loaded with a gas mixture containing $5 \% \mathrm{CO}_{2}$ and $95 \% \mathrm{~N}_{2}(\mathrm{v} / \mathrm{v})$ for $5 \mathrm{~min}$ at $20 \mathrm{~L} \mathrm{~min}^{-1}$. The cell cultures within the anaerobic chamber were kept in a humidified incubator at $37{ }^{\circ} \mathrm{C}$ for $12 \mathrm{~h}$. The morphology of primary cortical neurons and cell viability were measured respectively. 
4.2.6 Detection of the morphology and cell viability. OGD treatment can cause long-lasting damage to the central nervous system (CNS) and significant cell death. After OGD $12 \mathrm{~h}$, the differences of morphology about neurons were detected under invert microscope. Meanwhile, cell viability was determined by conventional MTT assay. The cells in 48-well plates were incubated with MTT $\left(0.5 \mathrm{mg} \mathrm{mL} \mathrm{mL}^{-1}\right.$ in final concentration, $10 \%$ volume of medium) for $4 \mathrm{~h}$ at $37^{\circ} \mathrm{C}$. Then, the formazan crystals were dissolved in DMSO, and the optical density (OD) was measured at $492 \mathrm{~nm}$ with a Microplate reader (Thermo Scientific, Mx3000P). Cell viability was expressed as a percentage of the optical density (OD) value of the control cultures.

\section{Conflicts of interest}

There are no conflicts to declare.

\section{Acknowledgements}

This work was supported by the project 201602707 Natural Science Foundation of Liaoning Province.

\section{Notes and references}

1 A. S. Go, D. Mozaffarian, V. L. Roger, E. J. Benjamin, J. D. Berry, W. B. Borden, D. M. Bravata, S. Dai, E. S. Ford, C. S. Fox, S. Franco, H. J. Fullerton, C. Gillespie, S. M. Hailpern, J. A. Heit, V. J. Howard, M. D. Huffman, B. M. Kissela, S. J. Kittner, D. T. Lackland, J. H. Lichtman, L. D. Lisabeth, D. Magid, G. M. Marcus, A. Marelli, D. B. Matchar, D. K. McGuire, E. R. Mohler, C. S. Moy, M. E. Mussolino, G. Nichol, N. P. Paynter, P. J. Schreiner, P. D. Sorlie, J. Stein, T. N. Turan, S. S. Virani, N. D. Wong, D. Woo and M. B. Turner, Circulation, 2013, 127, e6-e245.

2 J. D. Pandian, V. Padma, P. Vijaya, P. N. Sylaja and J. M. Murthy, Int. J. Stroke., 2007, 2, 17-26.

3 X. Chen and K. Wang, Acta Pharm. Sin. B, 2016, 6, 522-530. 4 I. D. Kilic, A. Hakeem, K. Marmagkiolis, A. Paixao, I. Grunwald, D. Mutlu, S. Abou-Sherif, B. Gundogdu, S. Kulaksizoglu, I. Ates, M. Wholey, O. Goktekin and M. Cilingiroglu, Cardiovasc. Revasc. Med., 2018, DOI: 10.1016/j.carrev.2018.07.010.

5 Z. H. Mu, Z. Jiang, X. J. Lin, L. P. Wang, Y. Xi, Z. J. Zhang, Y. T. Wang and G. Y. Yang, CNS Neurosci. Ther., 2016, 22, 316-324.

6 T. Zhang, W. Yan, Q. Li, J. Fu, K. Liu, W. Jia, X. Sun and X. Liu, Neurol. Res., 2011, 33, 396-404.

7 A. M. Rao, J. F. Hatcher and R. J. Dempsey, J. Neurosci. Res., 1999, 58, 697-705.

8 H. Guo, I. Singh, Y. Wang, R. Deane, T. Barrett, J. A. Fernández, N. Chow, J. H. Griffin and B. V. Zlokovic, Eur. J. Neurosci., 2009, 29, 1119-1130.

9 X. Zhao, R. Strong, P. Piriyawat, R. Palusinski, J. C. Grotta and J. Aronowski, Stroke, 2010, 41, 363-367.

10 D. M. Abdallah, N. N. Nassar and R. M. Abd-El-Salam, Brain Res., 2011, 1385, 257-262.
11 Z. H. Zhou, J. F. Lu, W. W. Liu, A. Manaenko, X. H. Hou, Q. Y. Mei, J. L. Huang, J. P. Tang, J. H. Zhang, H. G. Yao and Q. Hu, Pharmacol. Ther., 2018, 191, 23-42.

12 (a) K. Szydlowska and M. Tymianski, Calcium, Cell Calcium, 2010, 47, 122-129; (b) E. Candelario-Jalil, Curr. Opin. Invest. Drugs, 2009, 10, 644-654.

13 J. Wu, J. Ling, X. Wang, T. Li, J. Liu, Y. Lai, H. Ji, S. Peng, J. Tian and Y. Zhang, J. Med. Chem., 2012, 55, 7173-7181.

14 S. Panagiotou and S. Saha, Front. Neurosci., 2015, 9, 182.

15 H. Chen, H. Yoshioka, G. S. Kim, J. E. Jung, N. Okami, H. Sakata, C. M. Maier, P. Narasimhan, C. E. Goeders and P. H. Chan, Antioxid. Redox Signaling, 2011, 14, 1505-1517. 16 M. Cini and A. Moretti, Neurobiol. Aging, 1995, 16, 53-57.

17 P. H. Chan, C. J. Epstein, H. Kinouchi, H. Kamii, S. F. Chen, E. Carlson, J. Gafni, G. Yang and L. Reola, Adv. Neurol., 1996, 71, 271-280.

18 K. Murakami, T. Kondo, M. Kawase, Y. Li, S. Sato, S. F. Chen and P. H. Chan, J. Neurosci., 1998, 18, 205-213.

19 K. Suzuki, Adv. Drug Delivery Rev., 2009, 61, 287-289.

20 Y. Zang, X. Song, C. Li, J. Ma, S. Chu, D. Liu, Q. Ren, Y. Li, N. Chen and D. Zhang, Eur. J. Med. Chem., 2018, 143, 438448.

21 K. Y. Dae, K. K. Sun, S. H. Young, J. M. Kook, Y. S. Eun, P. S. Sup, S. H. Woo and Y. S. Wan, KR100769732B[P], 2007-10-23.

22 https://integrity.thomson-pharma.com/integrity/xmlxsl/ pk_prod_list.xml_prod_list_card_pr?

p_id=129588\&p_tsearch $=$ A.

23 C. Reis, O. Akyol, W. M. Ho, C. Araujo, L. Huang, R. Applegate II and J. H. Zhang, BioMed Res. Int., 2017, 2017, 4863079.

24 F. M. C. Barros, B. Pippi, R. R. Dresch, D. Betina, S. C. Luciano, M. A. Apel, A. M. Fuentefria and G. L. von Poser, Ind. Crops Prod., 2013, 44, 294-299.

25 L. Wang, G. Chen, X. Lu, S. Wang, S. Han, Y. Li, G. Ping, X. Jiang, H. Li, J. Yang and C. Wu, Eur. J. Med. Chem., 2015, 89, 88-97.

26 Q. Hong, Z. C. Ma, H. Huang, Y. G. Wang, H. L. Tan, C. R. Xiao, Q. D. Liang, H. T. Zhang and Y. Gao, Eur. J. Pharmacol., 2016, 777, 1-8.

27 Y. Deng, N. Wang, Q. Zhu, X. M. Xie, J. A. Duan and A. W. Ding, Pharmacol. Clin. Chin. Mater. Med., 2008, 32-34.

28 M. N. Liao, Y. P. Wang, Y. P. Zhang, R. D. Ma, X. Y. Zhang, L. J. Yu and T. X. Yu, Chin. J. Cell Biol., 2010, 32, 840-849.

29 L. Luo and Y. Sun, J. Chin. Med. Mater., 2011, 34, 1750-1753.

30 P. Agon, P. Goethals, D. V. Haver and J. M. Kaufman, J. Pharm. Pharmacol., 1991, 43, 597-600.

31 S. Y. Xu, Y. F. Hu, W. P. Li, Y. M. Wu, Z. Ji, S. N. Wang, K. Li and S. Y. Pan, Int. J. Biol. Sci., 2014, 10, 873-881.

32 C. G. Zhao, L. W. Zhang, H. Wang and D. Y. Huang, Food Sci., 2005, 26, 215-222.

33 B. Wu, L. Zhou and H. H. Cai, Chin. Chem. Lett., 2008, 19, 1163-1166.

34 T. Wu, W. Wang, X. S. Ding, M. J. Feng, Y. Gao and W. B. Yin, Pharmaceutical and Clinical Research, 2007, 15, 347-351. 